OAK

RIDGE

NATIONAL

LABORATORY

\title{
Oak Ridge TNS Program: \\ Evaluation of a Secondary Vacuum Enclosure for TNS
} CARBIDE

Carl Sardella

OPERATED BY

UNION CARBIDE CORPORATION FOR THE UNITED STATES DEPARTMENT OF ENERGY 


\section{DISCLAIMER}

This report was prepared as an account of work sponsored by an agency of the United States Government. Neither the United States Government nor any agency Thereof, nor any of their employees, makes any warranty, express or implied, or assumes any legal liability or responsibility for the accuracy, completeness, or usefulness of any information, apparatus, product, or process disclosed, or represents that its use would not infringe privately owned rights. Reference herein to any specific commercial product, process, or service by trade name, trademark, manufacturer, or otherwise does not necessarily constitute or imply its endorsement, recommendation, or favoring by the United States Government or any agency thereof. The views and opinions of authors expressed herein do not necessarily state or reflect those of the United States Government or any agency thereof. 


\section{DISCLAIMER}

Portions of this document may be illegible in electronic image products. Images are produced from the best available original document. 


\section{Printed in the United States of America. Available from National Technical Information Service \\ U.S. Department of Commerce}

b'żs rort Royal Road, Sprlngfleld, Viryinid 22161

NTIS price codes-Printed Copy: A05; Microfiche A01

This report was prepared as an account of work sponsored by an agency of the United States Government. Neither the United States nor any agency thereof, nor any of their employees, makes any warranty, expressed or implied, or assumes any legal liability or responsibility for any third party's use or the results of such use of any information, apparatus, product or process disclosed in this report, or represents that its use by such third party would not infringe privately owned rights. 
ORNL/TM-6725

Dist. Category UC-20 d

Contract No. W-7405-eng-26

FUSION ENERGY DIVISION

OAK RIDGE TNS PROGRAM: EVALUATION OF A SECONDARY

VACUUM ENCLOSURE FOR TNS

Carl Sardella

Grumman Aerospace Corporation

Date Published - November 1979

Trepared by the

OAK RIDGE NATIONAL LABORATORY

Dak Ridge, Tennessee 37830

operated by

UNION CARBIDE CORPORATION

for the

DEPARTMENT OF ENERGY 


\section{THIS PAGE}

\section{WAS INTENTIONALLY LEFT BLANK}


CONTENTS

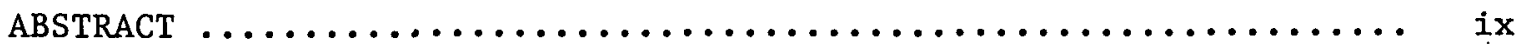

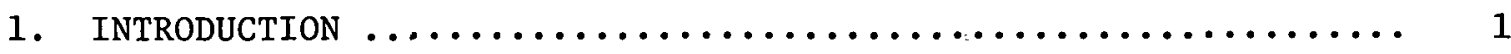

1.1 OVERVIEW OF THE NEXT STEP (TNS) STUDY $\ldots \ldots \ldots \ldots \ldots \ldots \ldots \ldots 1$

1.2 PURPOSE FOR INVESTIGATING A SECONDARY VACUUM

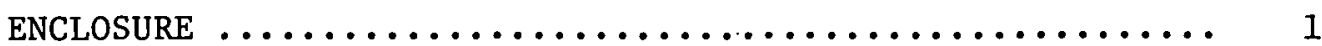

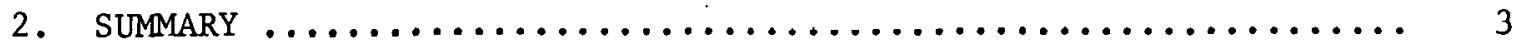

3. SELECTING THE PREFERRED SECONDARY VACUUM ENCLOSURE

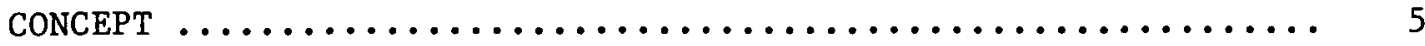

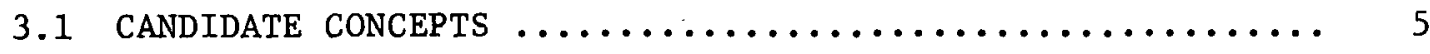

3.2 EVALUATION CRITERIA ........................ 7

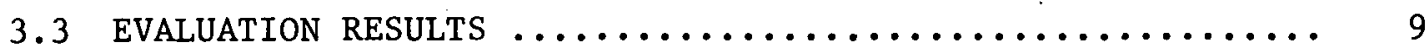

4. DESIGN DESCRIPTION $\ldots \ldots \ldots \ldots \ldots \ldots \ldots \ldots \ldots \ldots \ldots \ldots \ldots \ldots \ldots \ldots \ldots \ldots \ldots \ldots$

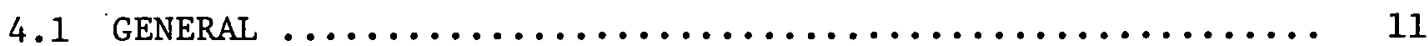

4.2 THE VACUUM BUILDING $\ldots \ldots \ldots \ldots \ldots \ldots \ldots \ldots \ldots \ldots \ldots \ldots \ldots \ldots \ldots \ldots \ldots \ldots$

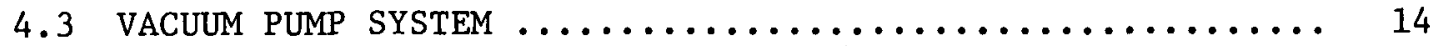

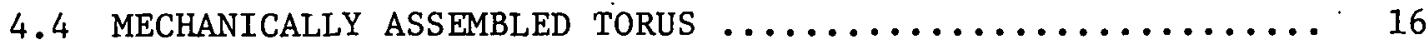

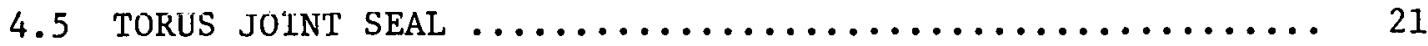

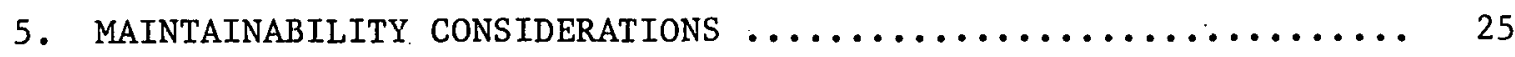

5.1 MAINTENANCE MODES - VACUUM VS ATMOSPHERIC ........... 25

5.2 VACUUM-RATED REMOTE MAINTENANCE SYSTEM EQUIPMENT $\ldots \ldots \ldots .26$

5.3 NONVACUUM-RATED REMOTE MAINTENANCE SYSTEM

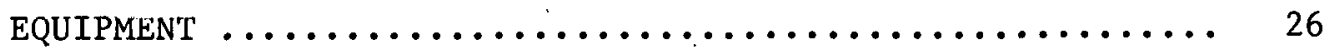

5.4 SCHEdUled MaINTENANCE PERIOdS $\ldots \ldots \ldots \ldots \ldots \ldots \ldots \ldots \ldots \ldots \ldots$

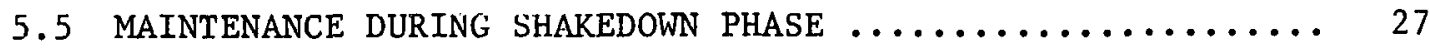

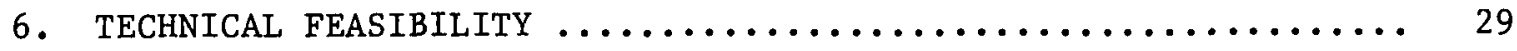

6.1 ELECTRICAL SYSTEMS .......................... 29

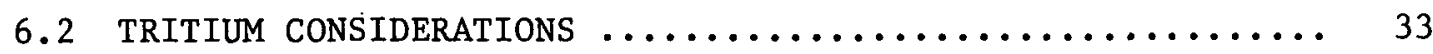

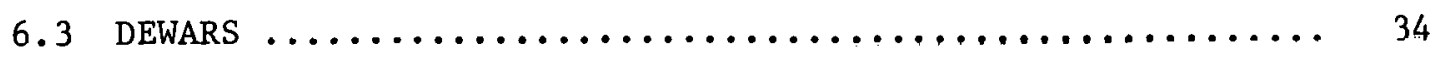

6.4 BASE PRESSURE OF A VACUUM BUILDING ............... 36 


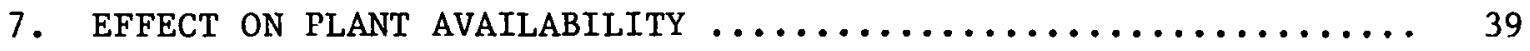

7.1 VACUUM BUILDING COMMERCIAL POWER REACTOR ........... 39

7.2 ATMOSPHERIC BUILDING COMMERCIAL POWER REACTOR ......... 41

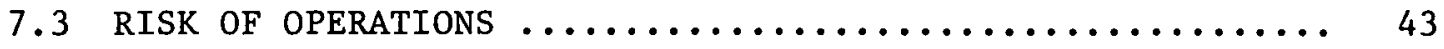

8. COS' vS BENEFITS $\ldots \ldots \ldots \ldots \ldots \ldots \ldots \ldots \ldots \ldots \ldots \ldots \ldots \ldots \ldots \ldots \ldots \ldots$

9. CONCLUSIONS AND RECOMMENDATIONS $\ldots \ldots \ldots \ldots \ldots \ldots \ldots \ldots \ldots \ldots \ldots$

9.1 CONCLUSIONS $\ldots \ldots \ldots \ldots \ldots \ldots \ldots \ldots \ldots \ldots \ldots \ldots \ldots \ldots \ldots \ldots \ldots \ldots \ldots$

9.2 RECOMMENDATIONS $\ldots \ldots \ldots \ldots \ldots \ldots \ldots \ldots \ldots \ldots \ldots \ldots \ldots \ldots$

APPENDIX A - MAINTENANCE TASKS AND TIME ESTIMATES TO REPLACE SECTORS OF A VACUUM BUILDING COMMERCIAL POWER REACTOR .............................. 49

APPENDIX B - MAINTENANCE TASKS AND TIME ESTIMATES TO REPLACE SECTORS OF A NONVACUUM BUILDING COMMERCIAL POWER REACTOR ............................. 55

APPENDIX C - MAINTENANCE TASKS AND TIME ESTIMATES TO REPLACE ONE SECTOR OF A TNS DEVICE HAVING A MECHANICALLY ASSEMBLED TORUS

APPENDIX D - MAINTENANCE TASKS AND TIME ESTIMATES TO REPLACE ONE SECTOR OF A 'INS DEVICE HAVING A WELDED TORUS

APPENDIX E - CALCULATION OF SEAL CONDUCTANCE

APPENDIX F - CALCULATION OF TORUS VACUUM PUMP SPEED REQUIRED AT VARIOUS INLEAK RATES 


\section{FIGURES}

3.1 SECONDARY VACUUM ENCLOSURE CONCEPTS $\ldots \ldots \ldots \ldots \ldots \ldots \ldots \ldots$

4.1 VACUUM BUILDING - ELEVATION $\ldots \ldots \ldots \ldots \ldots \ldots \ldots \ldots \ldots \ldots \ldots \ldots$

4.2 VACUUM BUILDING - PLAN VIEW $\ldots \ldots \ldots \ldots \ldots \ldots \ldots \ldots \ldots \ldots \ldots$

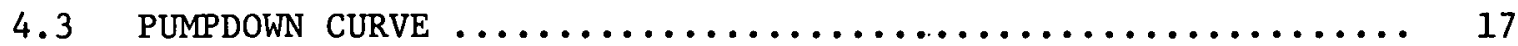

4.4 TNS REFERENCE DESIGN - ELEVATION $\ldots \ldots \ldots \ldots \ldots \ldots \ldots \ldots \ldots \ldots$

4.5 TNS REFERENCE DESIGN - PLAN VIEW $\ldots \ldots \ldots \ldots \ldots \ldots \ldots \ldots \ldots \ldots$

4.6 SECTION THROUGH TORUS JOINT $\ldots \ldots \ldots \ldots \ldots \ldots \ldots \ldots \ldots \ldots \ldots \ldots \ldots . \ldots \ldots$

4.7 SECTOR REPLACEMENT PROCEDURE $\ldots \ldots \ldots \ldots \ldots \ldots \ldots \ldots \ldots \ldots \ldots \ldots \ldots$

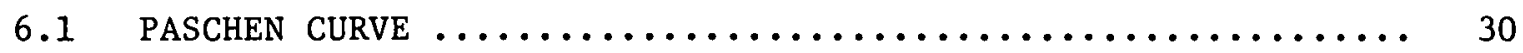

6.2 PRESSURE DEPENDENCE OF DIELECTRIC STRENGTH OF AIR ....... 31

6.3 EFFECT OF INLEAKAGE ON TORUS VACUUM PUMP SYSTEM $\ldots \ldots \ldots \ldots \ldots . . .37$

7.1 DETAIL OF TORUS JOINT; COMMERCIAL POWER REACTOR;

BOLTED ................................... 40

7.2 DETAIL OF TORUS JOINT; COMMERCIAL POWER REACTOR;

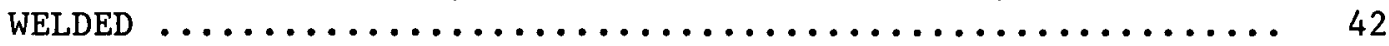




\section{THIS PAGE}

\section{WAS INTENTIONALLY LEFT BLANK}




\section{TABLES}

3.1 COMPARISON OF SECONDARY VACUUM ENCLOSURE CONCEPTS $\ldots \ldots \ldots \ldots$

4.1 COST COMPARISON OF A VACUUM BUILDING VS AN ATMOSPHERIC PRESSURE BUILDING ............................ 14

4.2 CELL VACUUM PUMP SYSTEM - PARAMETERS $\ldots \ldots \ldots \ldots \ldots \ldots \ldots \ldots \ldots$

4.3 CELL VACUUM PUMP SYSTEM - COMPONENTS ............... 18 


\section{THIS PAGE \\ WAS INTENTIONALLY \\ LEFT BLANK}


An objective of the TNS studies has been to define the characteristics and requirements of a facility dedicated to the engineering testing phase of fusion power development. The TNS study is a basis for defining an engineering test facility in which the design of the reactor core is based on the tokamak concept.

This report investigates the use of a secondary vacuum enclosure (SVE) to eliminate the need for high vacuum joints between torus sectors and thereby improve device maintainability.

Several conceptual SVE designs have been identified and evaluated and the vacuum building was selected as the most promising. A mechanically assembled torus having high impedance seals (rather than vacuum tight seals) between sectors is described and the mechanical characteristics of the device are discussed. Included in the SVE study were data regarding the effect of air leakage into the plasma chamber and tritium leakage out of the plasma chamber, and, thus, the seal integrity requirement.

From this study the size of the vacuum pump system and the pumpdown time for the vacuum building were determined. Studied also were the many aspects of the effect a vacuum environment has on tokamak systems. The potential benefits of using a SVE on a commercial reactor were investigated and stated in terms of improved plant availability. 


\section{INTRODUCTION}

\subsection{OVERVIEW OF THE NEXT STEP (TNS) STUDY}

The Next Step (TNS) represents that phase of fusion energy development in which the major emphasis would be directed toward engineering testing and demonstration. The objective of the TNS studies (initiated by the Department of Energy's Office of Fusion Energy) has been to define the characteristics and requirements of a facility dedicated to the engineering testing phase of fusion power development. For this reason, the TNS study results are providing a basis for defining an Engineering Test Facility (ETF). Because the scientific basis required for a TNS/ETF will first be available for the tokamak concept, the reactor core of the facility has been based on the tokamak concept. However, the commitment to an ETF with a reactor core based on the tokamak concept does not represent a commitment to tokamaks as the ultimate power reactor concept.

The TNS studies at Oak Ridge National Laboratory (ORNL) were initiated in FY 1977. During FY 1977 the Oak Ridge effort pursued scoping studies in three broad areas: plasma engineering, systems modeling, and program planning. Based on the findings of the FY 1977 efforts, it was judged that continued activities in the Oak Ridge TNS program should be directed toward preconceptual design with particular emphasis placed on engineering feasibility. As a point of departure for the FY 1978 activities, a baseline design was selected, based on the systems modeling effort of FY 1977. The primary objective of our FY 1978 TNS effort has been to evolve the Baseline Design toward a preconceptual design. However, it is emphasized that the FY 1978 effort was not intended to lead to a completed preconceptual design. Therefore, the design resulting from this year's effort is referred to as the Keference Design, rather than as the Precnnreptinal Destgn.

\subsection{PURPOSE FOR INVESTIGATING A SECONDARY VACUUM ENCLOSURE}

A major engineering problem that has surfaced in recent tokamak studies is the difficulty of access to the plasma chamber for the repair or replacement of in-vessel components. ${ }^{1-3}$ 
Presently, access is difficult because of the need for high vacuum integrity which dictates the use of welded torus joints. ${ }^{4}$ Access to these welds via exterior surfaces of the torus is virtually impossible because of the low aspect ratio and the closely spaced magnetic coils. Access to the welds via internal surfaces of the torus is extremely complex because of the closely nested blanket (or first wall) modules. As a result, the prospects of achieving acceptable maintainability of commercial devices based on the tokamak principle appear dim.

A possible solution is to remove the need for an absolute vacuum of the torus by providing a secondary vacuum enclosure (SVE). Torus sectors may then be joined by mechanical means rather than by welding, and the design freedom thus afforded utilized to improve device maintainability. 


\section{SUMMARY}

Several concepts for a secondary vacuum enclosure (SVE) have been identified and evaluated. The concepts considered include a double wall torus, a toroidal enclosure, two bell jar configurations, and a vacuum building. The vacuum building was the preferred concept on the basis of the accessibility for routine maintenance during device operation and the ability to replace torus sectors without dismantling the SVE structure.

A TNS reference design based on the vacuum building concept is described. The containment building, which is patterned after the NASA Space Power Facility at Plum Brook, Ohio, has a concrete outer shell and a metallic inner shell. The inner chamber, or reactor cell, is maintained at a base pressure of $10^{-4}$ torr. The time required to pump down from atmospheric pressure to base is six hours. Mechanical pumps and Roots blowers are used for roughing vacuum, and oil diffusion pumps are used for high vacuum.

The torus is composed of 16 sectors that are joined by bolting. Mechanical seals are used at torus joints. Based on an allowable incell tritium concentration of $40 \mu \mathrm{Ci} / \mathrm{m}^{3}$ and a SVE pump speed of $2 \times$ $10^{5}$ liters/sec, the allowable seal gap at torus joints is $1 \mathrm{~mm}$ high and $275 \mathrm{~cm}$ long, which is $1.15 \%$ of the total seal length. Thus, tightness of torus joint seals is not critical and a suitable design based on existing technology appears achlevable.

A limited amount of maintenance will be performed with the reactor cell at base pressure $\left(10^{-4}\right.$ torr $)$ by using vacuum-rated maintenance equipment. Two moblle servomanipulators will be used for in-vacuum work, a floor mounted unit and a bridge mounted unit. Since the speed, load capacity, and dexterity of these units will be limited because of design constraints imposed by the vacuum, some maintenance tasks will be beyond the capability of vacuum-rated equipment and will be performed with nonvacuum-rated equipment and with the reactor cell at atmospheric pressure. The time penalty for doing so is ten hours: two hours for repressurization, six hours for pumpdown, and two hours for a plasma chamber bakeout. 
For the first two years of operation, or the shakedown phase, TNS will be nonradfoactive and the torus joints will have temporary seals to allow operation at atmospheric pressure. All maintenance during this phase will be performed "hands-on."

The vacuum environment places a major constraint on the design and operation of electrical equipment within the cell. Insulation material for electrical equipment conductors must be resistant to the effects of flashover and corona discharge and must have a low outgassing rate. Conductor-to-conductor spacing and creepage path lengths must be selected for vacuum compatibility. Deactivation of electrical systems is required whenever the cell pressure is in the critical pressure range, between $10^{-2}$ and 10 torr, during which the probability of flashover and corona discharge is significantly increased.

The possibility of eliminating TF coil dewars was investigated. However, it was concluded that dewars should be retained despite the vacuum environment within the cell. The main reasons for dewar retention are: (1) to avoid cold trapping large quantities of tritium, (2) to prevent release of hydrogen gasses which create an explosion hazard during cell repressurization, and (3) to eliminate the. need for 'I' coil warmup/cooldown each time the cell is pressurized.

The cost penalty for a T'NS vacuim bullding is $\$ 20 . j$ mLllioin. The benefit derived from this design concept is the ability to replace sectors rapidly and at low risk to the maintenance operation. 


\section{SELECTING THE PREFERRED SECONDARY VACUUM ENCLOSURE CONCEPT}

\subsection{CANDIDATE CONCEPTS}

A secondary vacuum enclosure is a vacuum boundary located between the first wall (or primary vacuum enclosure) and the reactor cell walls. Figure 3.1 shows five SVE concepts beginning with the smallest configuration possible and progressing in size until the entire reactor cell is enclosed within the SVE.

Concept a has the SVE located just outside the first wall. Essentially, it is a dual wall torus with differential pumping between inner and outer walls. The torus is divided into sectors and two seals are required at each torus joint. The inner seal has a vacuum on both sides and therefore does not require a high contact force. The outer seal has a 1-atm pressure differential across its surface and therefore requires relatively high contact forces, accurately machined flanges, and a high degree of dimensional stability. Closely spaced and accurately torqued bolts are required around the entire torus joint, including within the central bore, to assure proper seal contact.

Concept $b$ is a toroidal structure enclosing the PF coil, the TF coils, and the torus. Atmospheric pressure loads are supported at the central bore and at the exterior SVE surface, resulting in a structurally efficient enclosure. The outer wall requires numerous penetrations for the neutral beam injector (NBI), vacuum pump, and divertor ducts. In order to permit sector replacement, the SVE must have large removable panels between each TF coil.

Concept $c$ is a bell jar SVE that is similar to concept b with the exception that the central bore is included within the enclosure. It requires the same outer wall penetration and provisions for sector replacement. By enclosing the central bore, the TF coil dewar design is simplified and cryogenic $\mathrm{OH}$ coils may be included within the dewar enclosure.

Concept d is similar to concept $c$ except that the SVE boundary is extended to include the torus peripheral equipment, thus eliminating drift tube and vacuum duct penetrations. A horizontal parting plane is used just below the torus level. To replace a torus sector, the upper 


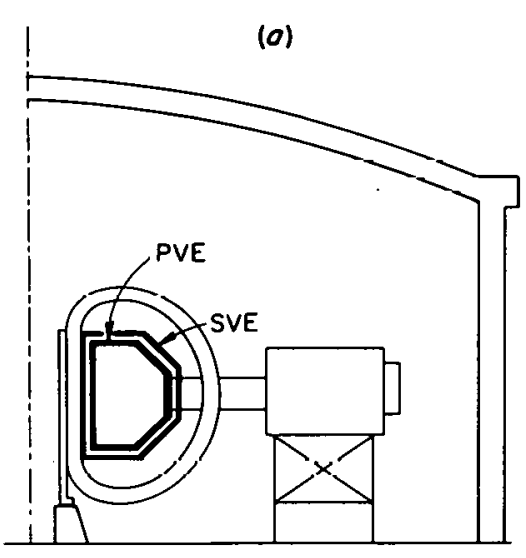

DUAL WALL TORUS

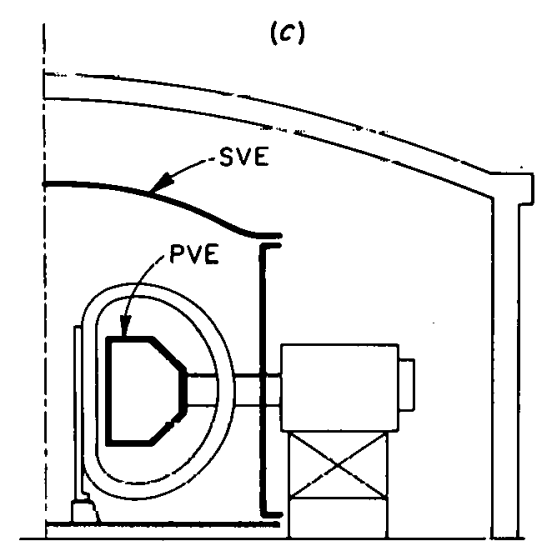

BELLJAR

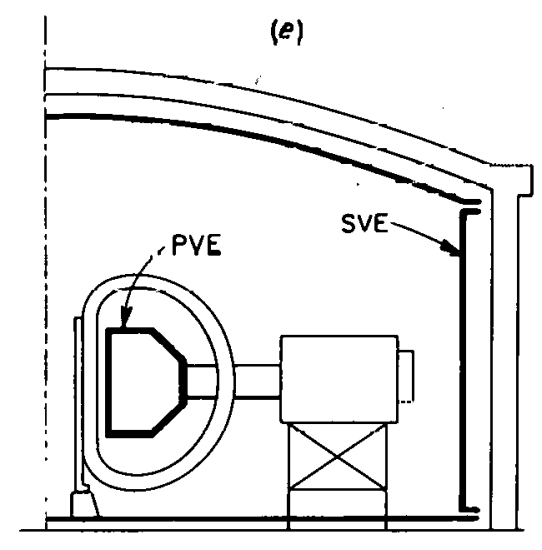

VACUUM BUILDING

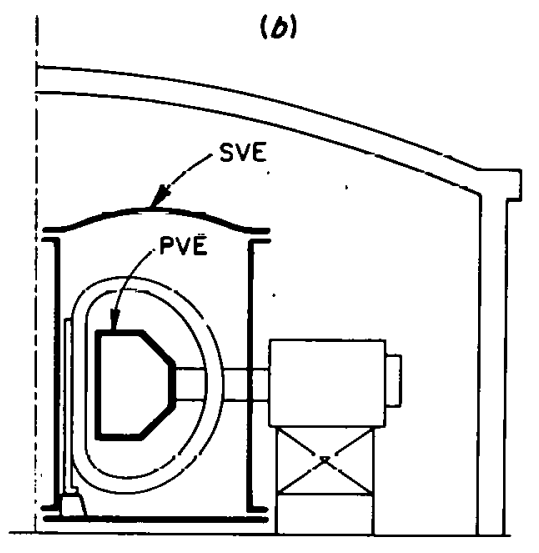

TOROIDAL ENCLOSURE

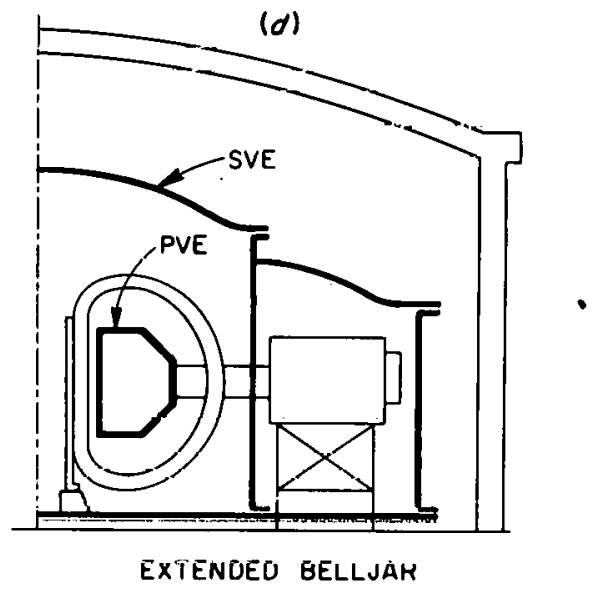

PVE = PRIMARY VACQUUM ENCLOSURE SVE = SECONDARY VACUUM ENCLOSURE

Fig. 3.1. SVE concepts. 
SVE section is raised and the sector is removed horizontally between two TF coils. An additional parting plane may be included in the removable portion of the SVE to allow removal in two operations. This will reduce the overall height of the reactor cell and the lifting capacity required for the SVE deployment mechanism.

Concept e is an SVE that encompasses the entire reactor cell and thereby results in a vacuum building. Torus sectors may be replaced without dismantling or deploying the SVE structure. Vacuum duct penetrations are not required, and access to the torus for inspection and maintenance purposes is not restricted by the structure of the SVE.

\subsection{EVALUATION CRITERIA}

The SVE concepts were rated on the basis of the following evaluation items :

1. Time required to replace a torus sector.

2. Ability to gain access to the torus for inspection and minor adjustments.

3. Impact on device design.

4. Impact on facility design.

5. Risk incurred during a major maintenance operation, such as torus sector replacement.

6. Cost.

Each concept was rated on a scale of 1 to 5 (5 being best) for each evaluation item. The following is a discussion of the rationale used to rate each concept.

Concept a (dual-walled torus) - An excessively high amount of time is needed to break the joint between torus sectors, due to the large number of bolts and the difflculty of gaining access to the central bore. A self-propelled bolt remover is required for this operation and must be used under adverse conditions of extreme confinement and poor visibility. Mechanical failure of the bolt remover would result in a retrieval operation which would be both lengthy and hazardous. 
The major advantages of concept a are the unrestricted access to the outer surfaces of the torus and the minimal impact on facility and device design.

Concept b - In order to replace a torus sector, an access panel measuring $8 \mathrm{~m}$ by $4 \mathrm{~m}$ and weighing approximately $30^{\circ}$ tons must be removéd. The panel may be either welded in place or mechanically sealed and bolted. Removal and replacement time for the access panel is estimated at 120 hours, and two panels must be removed for each sector replacement operation. Diagnostic equipment mounted on the torus may be serviced through smaller access ports by the use of specially designed equipment.

The NBI drift tubes and vacuum pump ducts require a SVE penetration which adds to their overall length. A relatively large area is required within the reactor cell to accommodate removal and stowage of SVE panels during device maintenance.

Concept $c$ - Maintenance characteristics for the bell jar concept are essentially the same as for concept b except for servicing requirements of the $\mathrm{OH}$ colls, which are not enclosed within the SVE and therefore are more accessible. In contrast to concept $b$, however, this concept permits use of a common dewar to enclose the 'l' $F$ ' coils and $\mathrm{OH}$ coils and is therefore less restrictive on the device design. As with concept $b$, the reactor cell size must be sized to permit removal and stowage of SVE panels. Operational risks are slightly reduced with concept $c$ as compared with concept b, due to increased access to the central bore.

Concept $d$ - Access to the torus for sector replacement necessitates a vertical movement plus a lateral translation of the upper section of the SVE. Although the time required to effecl Lhis mution is approximately the same as the time required to remove SVE paneis in concepts b and $c$, a somewhat greater risk is involved. This is due to the extensive mechanism required and the need to transfer the SVE section from a lifting device to a set of rails for lateral translation. However, considerably less impact is made on the device design with concept d because vacuum ducts to the torus need not penetrate the SVE and vacuum hardening of torus peripheral equipment is not required. Use of the vertical 
lifting device considerably increases the reactor cell height. Also, stowage area required for the upper SVE section adds to the reactor cell area required. Enclosing the torus peripheral equipment within the SVE necessitates servicing through access ports, hence making visual inspection extremely difficult.

Concept e - The vacuum building concept has a significant advantage over concepts $b, c$, and $d$, due to the ability to perform maintenance without dismantling or deploying the SVE structure. This characteristic leads to reduced maintenance times and relative safety of operations. Inspections and minor adjustments may be conducted in parallel with device operation with relative ease because of improved visibility and lack of interference by the SVE structure. However, since the entire cell is evacuated, it is necessary to design both device and facility for vacuum. Also, remote maintenance equipment must remain stowed within the cell during device operations (such as a polar crane), although not required to be operable within the vacuum, and it must be designed to withstand lengthy vacuum exposure times.

\subsection{EVALUATION RESULTS}

Table 3.1 lists the rating number assigned for each evaluation item. In order to account for relative importance, each evaluation item was assigned a weight factor of 1 to 10 , and ratings were multiplied by this factor to give a "weighted rating." Table 3.1 scores each SVE concept by giving the total number of weighted rating points. The vacuum building concept has the highest weighted rating total and on this basis is judged to be the most promising SVE concept. The strongest features of the vacuum building, which contribute to its success, are the ease with which sectors are replaced and the relatively low risk incurred during maintenance operations. 
Table 3.1 Comparison of SVI concepts

\begin{tabular}{|c|c|c|c|c|c|c|c|c|c|c|c|c|c|c|c|c|c|c|c|}
\hline \multirow{3}{*}{ Concept } & \multicolumn{19}{|c|}{ Evaluated item } \\
\hline & \multicolumn{3}{|c|}{$\begin{array}{l}\text { Ease of sector } \\
\text { replacement }\end{array}$} & \multicolumn{2}{|c|}{ Access to } & \multirow{2}{*}{$\frac{\text { torus }}{\text { WR }}$} & \multicolumn{3}{|c|}{$\begin{array}{l}\text { Impact on } \\
\text { tokamal design }\end{array}$} & \multicolumn{3}{|c|}{$\begin{array}{c}\text { Impact on } \\
\text { facility design }\end{array}$} & \multicolumn{3}{|c|}{$\begin{array}{c}\text { Rist of } \\
\text { maintenance } \\
\text { operation }\end{array}$} & \multicolumn{3}{|c|}{ Cost } & \multirow[t]{2}{*}{$\begin{array}{l}\text { Total } \\
\text { weighted } \\
\text { rating }\end{array}$} \\
\hline & $\mathrm{R}^{a}$ & $w^{3}$ & $W_{R}^{c}$ & $\mathbf{F}$ & $\mathrm{W} \Xi$ & & $\mathbf{R}$ & WE & WR & $\mathbf{R}$ & WF & $\dot{W R}$ & $\mathrm{R}$ & $W^{\top} \mathrm{F}$ & WR & $\mathbf{R}$ & WF & WR & \\
\hline Dua1-wal1 torus & 1 & 10 & 10 & 5 & 3 & 15 & 5 & 3 & 15 & 5 & 3 & 15 & 1 & 10 & 10 & 5 & 1 & 5 & 70 \\
\hline Toroidal enclosure & 3 & 10 & 3.5 & 2 & 3 & 6 & 1 & 3 & 3 & 3 & 3 & 9 & 2 & 16 & 20 & 4 & 1 & 4 & 72 \\
\hline Bell jar & 3 & 10 & $3 J$ & 2 & 3 & 6 & 4 & 3 & 12 & 3 & 3 & 9 & 3 & $1 C$ & 30 & 4 & 1 & 4 & 91 \\
\hline Extended bell jar & 3 & 10 & 33 & 1 & 3 & 3 & 5 & 3 & 15 & 2 & 3 & 6 & 2 & $1 C$ & 20 & 2 & 1 & 2 & 76 \\
\hline Vacuum building & 5 & 10 & כ5 & 5 & 3 & 15 & 1 & 3 & 3 & 1 & 3 & 3 & 5 & 10 & 50 & 1 & 1 & 1 & 122 \\
\hline
\end{tabular}

$a_{\text {Rating. }}$

$b_{\text {Weight factor. }}$

$c_{\text {Weighted rating. }}$ 


\section{DESIGN DESCRIPTION}

\subsection{GENERAL}

The purpose of this section is to identify a TNS design based on the vacuum building concept in order to examine feasibility issues and to permit comparison with a non-SVE design.

\subsection{THE VACUUM BUILDING}

The containment structure is a vacuum building having a concrete outer shell and a metallic inner shell as shown in Figs. 4.1 and 4.2. Its features are similar to the NASA Space Power Facility at Plum Brook, Ohio, 5 which was designed for environmental testing of space vehicles. It is approximately two-thirds the size of the TNS building.

The concrete shell of the TNS building is $60 \mathrm{~m}$ in diameter, $39 \mathrm{~m}$ high, and $2.0 \mathrm{~m}$ thick. It supports the atmospheric pressure loads and serves as the environmental shield. The wall thickness is sized for shielding requirements rather than for structural requirements; hence, its cost closely parallels that of a facility designed for atmospheric pressure. A steel liner, approximately $0.6 \mathrm{~cm}$ thick, is embedded within the concrete to minimize gas permeation through the wall.

The inner shell is $39 \mathrm{~m}$ in diameter, $33 \mathrm{~m} \mathrm{high,} \mathrm{and} 1.0 \mathrm{~cm}$ thick. Interior dimensions are determined by the space needed for the transporting and the staging of equipment during maintenance operations. The inier shell must support both internal and external pressure loads. A small internal pressure, approximately $0.05 \mathrm{~atm}$, is applied during leak checking and a 20-torr external pressure is applied during normal operating conditions.

Base pressure of the reactor cell is $10^{-4}$ torr. The rationale used for selection of this pressure is given in sect. 6. The purpose of the 20-torr pressure between inner and outer walls is to minimize outgassing of concrete surfaces.

The vacuum building doors are $6 \mathrm{~m}$ wide and $13 \mathrm{~m} \mathrm{high}$, as required to allow passage of a TF coil, and are sealed with an inflatable elastomeric gasket. A passageway commecls the vacuum building with the 
ORNL / OWG/FED 78-1177A

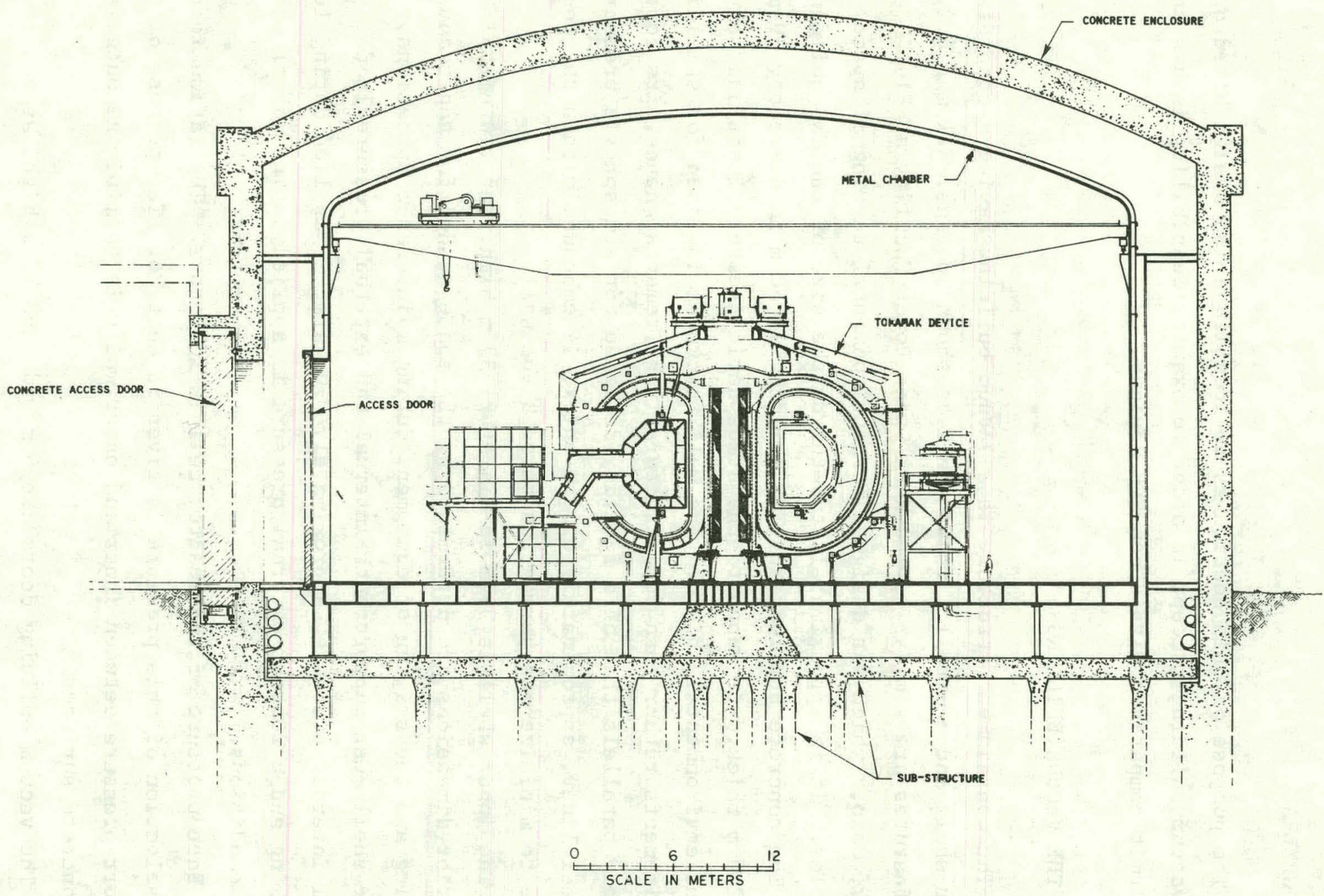

Fig. 4.1. Vacuum building elevaticn. 


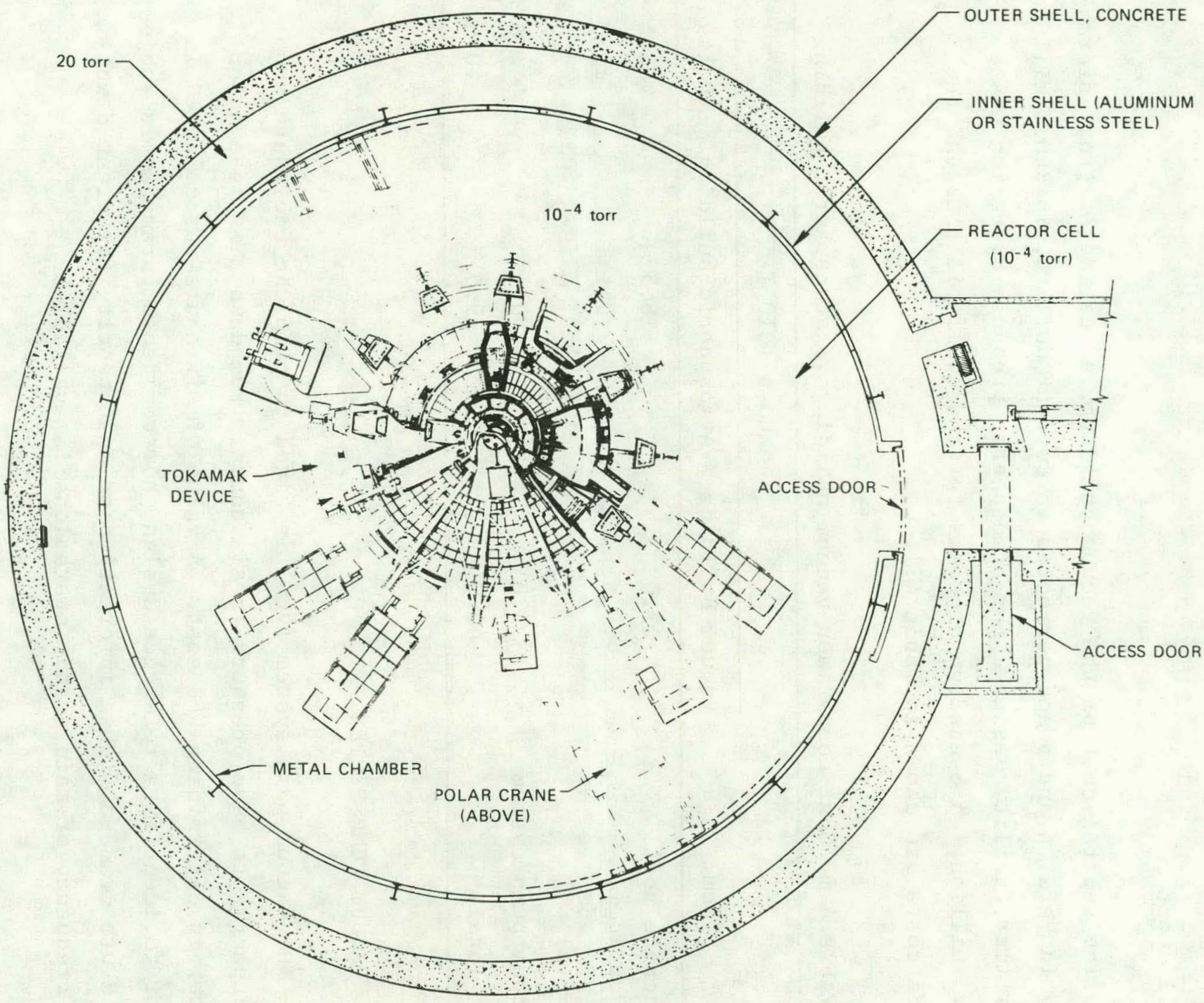

Fig. 4.2. Vacuum building plan view. 
maintenance cell. Since ingress/egress of maintenance equipment is made with the reactor cell at atmospheric pressure, the connecting passageway does not require air locks.

\subsubsection{Cost}

The capital cost of the vacuum building, as estimated from information in Refs. 4 and 5 and corrected to current dollars, is $\$ 40.0$ million. A similar facility designed for atmospheric pressure operation costs $\$ 19.5$ million. A breakdown of costs for the two facilities and the delta costs are shown in Table 4.1 .

Table 4.1 Cost comparison vacuum building vs atmospheric building

\begin{tabular}{lccr} 
& & Cost $\left(\$ 10^{6}\right)$ & \\
\cline { 2 - 4 } \multicolumn{1}{c}{ Item } & Vacuum building & Atmospheric building & Delta \\
\hline Concrete shell & 22.0 & 18.5 & 3.5 \\
Inner shel1 & 11.0 & 0 & 11.0 \\
Door(s) & 3.0 & 1.0 & 2.0 \\
Vacuum pump system & $\underline{4.0}$ & $\underline{0}$ & $\underline{4.0}$ \\
$\quad$ Total & 40.0 & 19.5 & 20.5 \\
\hline
\end{tabular}

\subsection{VACUUM PUMP SYSTEM}

The vacuum pump system (VPS) is sized to pump the enclosure from atmospheric to base pressure in six hours. Pumpdown time is a major factor in determining VPS cost. A value of six hours was selected in order to identify a reference design; however, this parameter is subject to future trade-oft when information un cost penalty for plant duwntime and frequency of maintenance operations is available.

\subsubsection{Calculation of Pump Speed}

The parameters used to calculate pump speed are given in Table 4.2. 
Table 4.2 Ce11 VPS - parameters

\begin{tabular}{ll}
\hline Base pressure & $\mathrm{P}=10^{-4}$ torr \\
$\begin{array}{l}\text { Volume of the cell } \\
\begin{array}{l}\text { Specific outgas rate } \\
\text { Outgassing area }\end{array}\end{array}$ & $\mathrm{V}=5.5 \times 10^{7}$ liter \\
$\begin{array}{l}\text { Inleak rate } \\
\begin{array}{l}\text { Roughing pressure } \\
\text { Mechanical pumps }\end{array}\end{array}$ & $\mathrm{A}=3.2 \times 10^{8} \mathrm{~cm}^{2}$ \\
$\begin{array}{l}\text { Roughing pressure } \\
\text { Roots pumps }\end{array}$ & 20 torr \\
$\begin{array}{l}\text { Ratio of pump speed } \\
\text { Mechanical: Roots and mechanical }\end{array}$ & $1: 0$ torr 1 iter $/ \mathrm{sec}$ \\
\hline
\end{tabular}

Roughing pump speed - For the initial pumpdown phase, from atmospheric to $10^{-3}$ torr, the pump speed is governed by the gas content within the enclosure, and the time-vs-pressure relation is: ${ }^{6}$

$$
P=P_{i} e^{(-s t / v)},
$$

where

$$
\begin{aligned}
P & =\text { pressure at } \text { time } t \\
\mathbf{3} & =\text { pump speed } \\
\mathrm{v} & =\text { cell volume } \\
\mathrm{P}_{i} & =\text { initial pressure. }
\end{aligned}
$$

High vacuum pump speed - During the final pumpdown phase, outgas load and inleakage rate are the significant pump throughput, and the timevs-pressure relation is: ${ }^{6}$

$$
P V=P_{i} V+\sum Q_{0} \Delta t+\sum Q_{L} \Delta t-P S \Delta t
$$


where

$$
\begin{aligned}
S & =\text { pump speed } \\
\Delta t & =\text { increment of time } \\
P_{i} & =\text { pressure at start of } \Delta t \\
Q_{0} & =\text { outgas load }=\text { qAt }^{-1} \\
Q_{L} & =\text { air inleakage. }
\end{aligned}
$$

Equations (4.1) and (4.2) werc solved for the conditions $P=10^{-3}$ torr at $t=5 \mathrm{hr}$, and $P=1 U$ ' torr a $L-6 \mathrm{hr}$, and the resilts are shown in the pumpdown curve (Fig. 4.3). Hump speeds needed to achieve the 6-hr pumpdown time are $2 \times 10^{4}$ liter/sec for the mechanical pumps, $8 \times 10^{4}$ liter/sec for the combined Roots and mechanical pumps, and $2 \times 10^{5}$ liter/ sec for the high-vacuum pumps.

\subsubsection{Description of VPS}

The vacuum pumps and isolation values selected for the reference design are shown in Table 4.3.

The space between the concrete and the metallic wall has one-half the reactor cell volume and must be pumped down to 20 torr. Therefore, it requires a pump speed one-half that of the mechanical pumps used for the reactor cell. Item (e) identifies the pumps required for interspace pumpdown.

The total cost of the VPS components, as purchascd commercially, is $\$ 2,669,000$. The cost of special provisions as required for remote servicing and tritium compatibillly is assumed at $50 \%$ of nriginal cost. Thus, the total cost of VPS components is $1.5 \times \$ 2,669,000$, or approx1mately $\$ 4.0$ million.

\subsection{MECHANICALLY ASSEMBLED TORUS}

The design objective of the mechanically assembled Lurus is to allow ease of sector replacement. Characteristics that contribute to this objective are the ability to: 


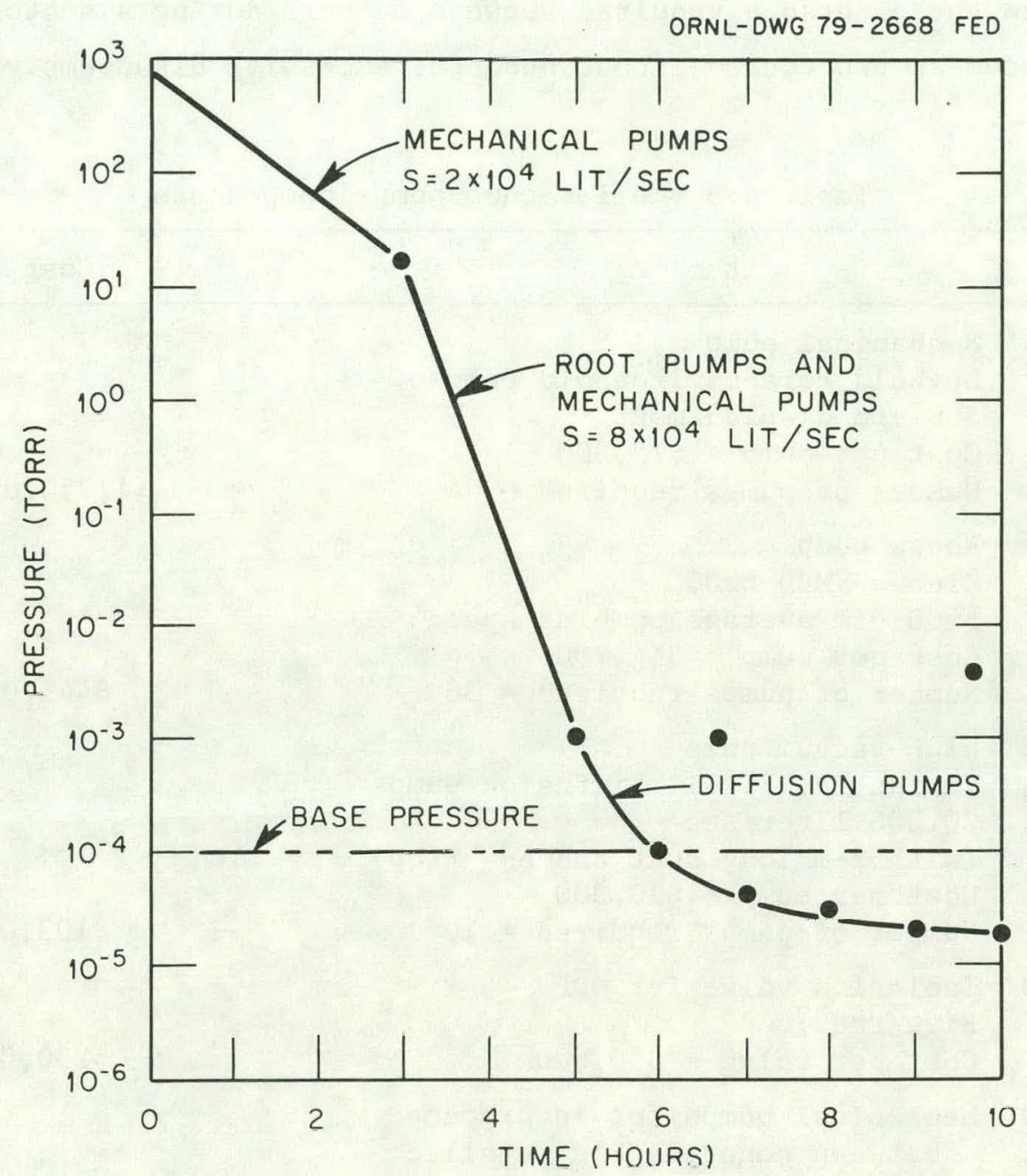

Fig. 4.3. Pumpdown curve for vacuum building. 
(1) replace sectors without in-vessel operations,

(2) accommodate dimensional variations between original and replacement sectors, and

(3) obtain the clearance required between sectors during a sector replacement procedure without need for excessive disassembly.

Table 4.3 Cell vacuum pumps components

\begin{tabular}{|c|c|c|}
\hline & Item & Cost \\
\hline (a) & $\begin{array}{l}\text { Mechanical pump } \\
\text { Teybold Heraeus Trochoid Pumps } \\
500 \mathrm{cfm} \text { displacement } \\
\text { Cust per pump }=\$ 13,300 \\
\text { Number of pumps required }=94\end{array}$ & $\$ 1,250, n \cap 0$ \\
\hline (b) & $\begin{array}{l}\text { Roots pump } \\
\text { Kinney KMBD } 6500 \\
5500 \mathrm{cfm} \text { average pumping speed } \\
\text { Cost per pump }=\$ 14,700 \\
\text { Number of pumps required }=30\end{array}$ & $\$ 441,000$ \\
\hline (c) & $\begin{array}{l}\text { High-vacuum pump } \\
\text { Varian NHS- } 35 \text { Oil Diffusion pump } \\
20,000 \text { liter } / \mathrm{sec} \\
\text { (with } 2-\mathrm{m} \text { lowy duct and } \mathrm{LN}_{2} \text { trap) } \\
\text { Cost per pump }=\$ 10,300 \\
\text { Number of pumps required }=10\end{array}$ & $\$ 103,000$ \\
\hline (d) & $\begin{array}{l}\text { Isolation valve for ODP } \\
\text { Five required } \\
\text { Cost per valve }=\$ 50,000\end{array}$ & $\$ 250,000$ \\
\hline (e) & $\begin{array}{l}\text { Mechanical pumps for interspace } \\
\text { between comirete and metallic } \\
\text { walls [same as item (a)] } \\
\text { Number of pumps required }=47\end{array}$ & $\$ 6,25,000$ \\
\hline & Total & $\$ 2,669,000$ \\
\hline
\end{tabular}

The torus is shown in the general arrangement drawings (Figs. 4.4 and 4.5). It is composed of 16 sectors joined by externally accessible bolts. When fully assembled, the sectors are in contact with two bucking rings which provide radial stiffness.

Vertical loads are carried by a torus support structure consisting of a circular rail and compression struts. The torus support structure is divided into four quadrants. Each supports four torus sectors and 
ORNL-DWG 79-2139 FED

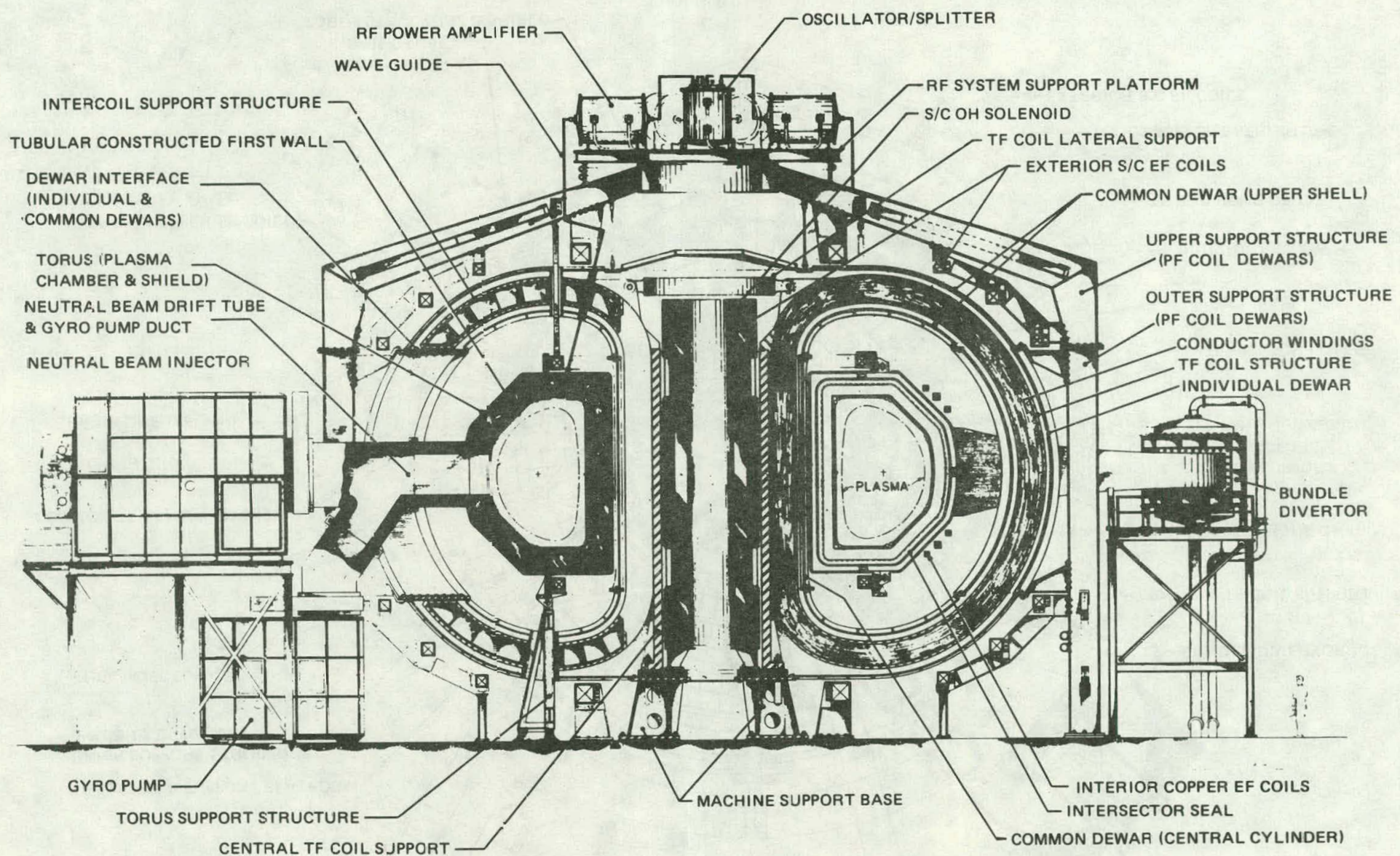

Fig. 4.4. TNS Reference Design elevation. 


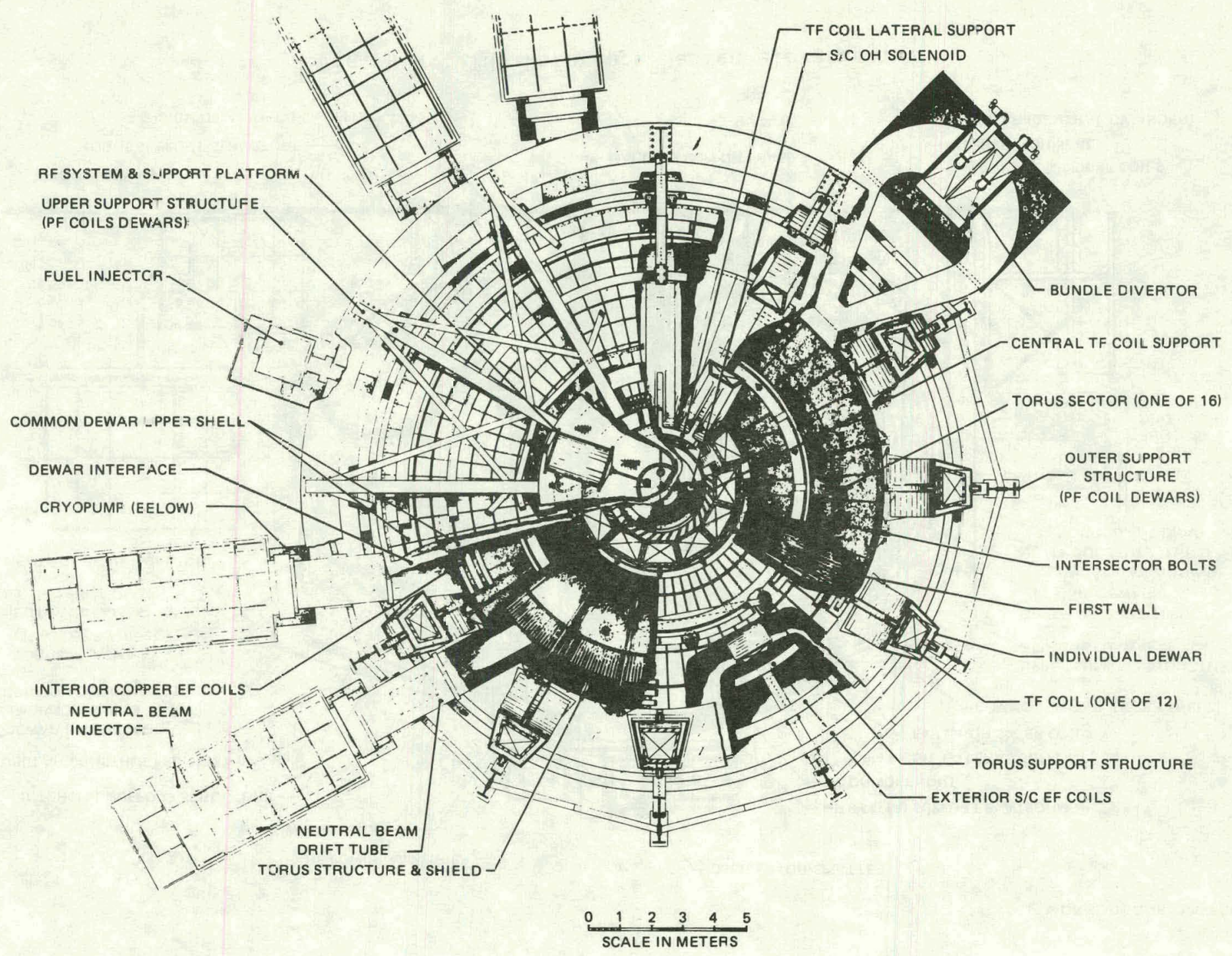

Fig. 4.5. TNS Reference Design plan view. 
may be moved radially out for a distance of $10 \mathrm{~cm}$ (to a stop position) by removing the sector attachment bolts and disengaging lateral locks at the base of the torus support structure. The vertical struts are pin-. ended to allow lateral motion. Jackscrews between the circular rail and the bucking ring are used for moving a quadrant radially out.

When a torus sector is disengaged from adjacent sectors, its overturning moments are resisted by the upper and lower circular rails which are supported by the bucking rings and the outer support structure.

Contact between adjacent torus sectors is made at three points. A uniform spacing of $4 \mathrm{~cm}$ is provided between sectors to allow space to mount the mechanical seals (see Fig. 4.6).

Torus sectors are removed and replaced through the horizontal opening between TF coils. There are $12 \mathrm{TF}$ coils and 16 torus sectors. One sector in each quadrant is in alignment between coils and can be removed directly; the remaining three sectors must be rotated into alignment beween coils prior to removal. The sequence of operations for sector replacement is shown in Fig. 4.7.

\subsection{TORUS JOINT SEAL}

Each torus joint contains two mechanical seals to maintain high Lupedance to molooular fin $\mathrm{nm}$. When the reactor cell is at vacuum, the pressure differential across the seals is essentially zero. When the reactor cell is at atmospheric pressure, the torus is filled with an inert gas to equalize internal and external pressures.

The seal must have a high degree of compliance to accommodate flange movement that occurs due to thermal distortion and dynamic loading. Contact force between seal and flange need only be minimal since small gaps, such as may result from surface roughness, are not critical. The seal width is large to provide high impedance to flow despite gaps in seal contact.

The torus joint seal is shown in Fig. 4.6. In cross section, it is a cantilevered spring with a 1-cm-wide seal element attached. The seal is D-shaped to conform with the flange contour. Several sharp bends are requircd and, to maintain a low spring gradient, slots are cut in the 


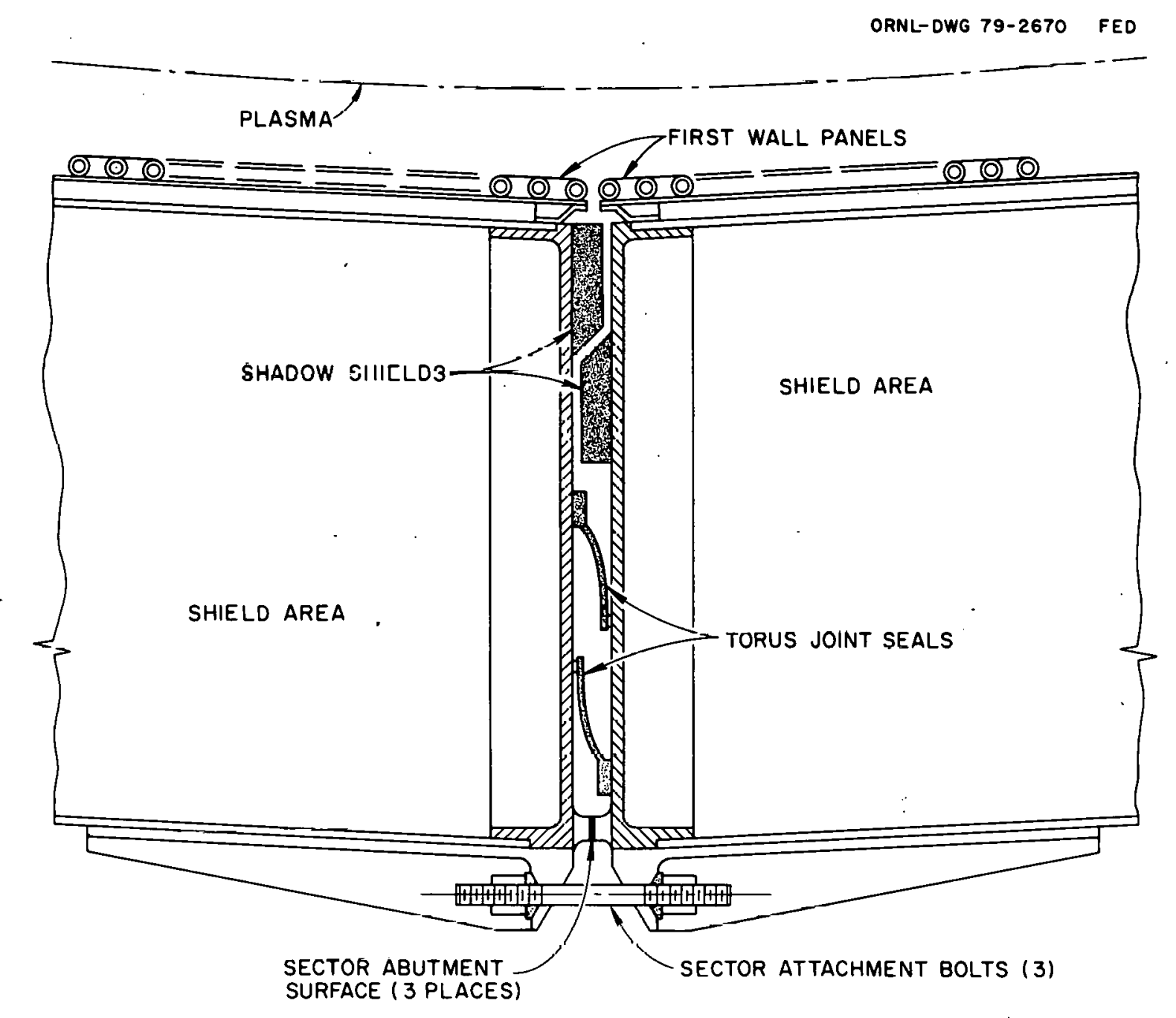

Fig. 4.6. Section through torus jolnt. 
ORNL/DWG/FED 78-1174

\section{SECTOR REPLACEMENT PROCEDURE}

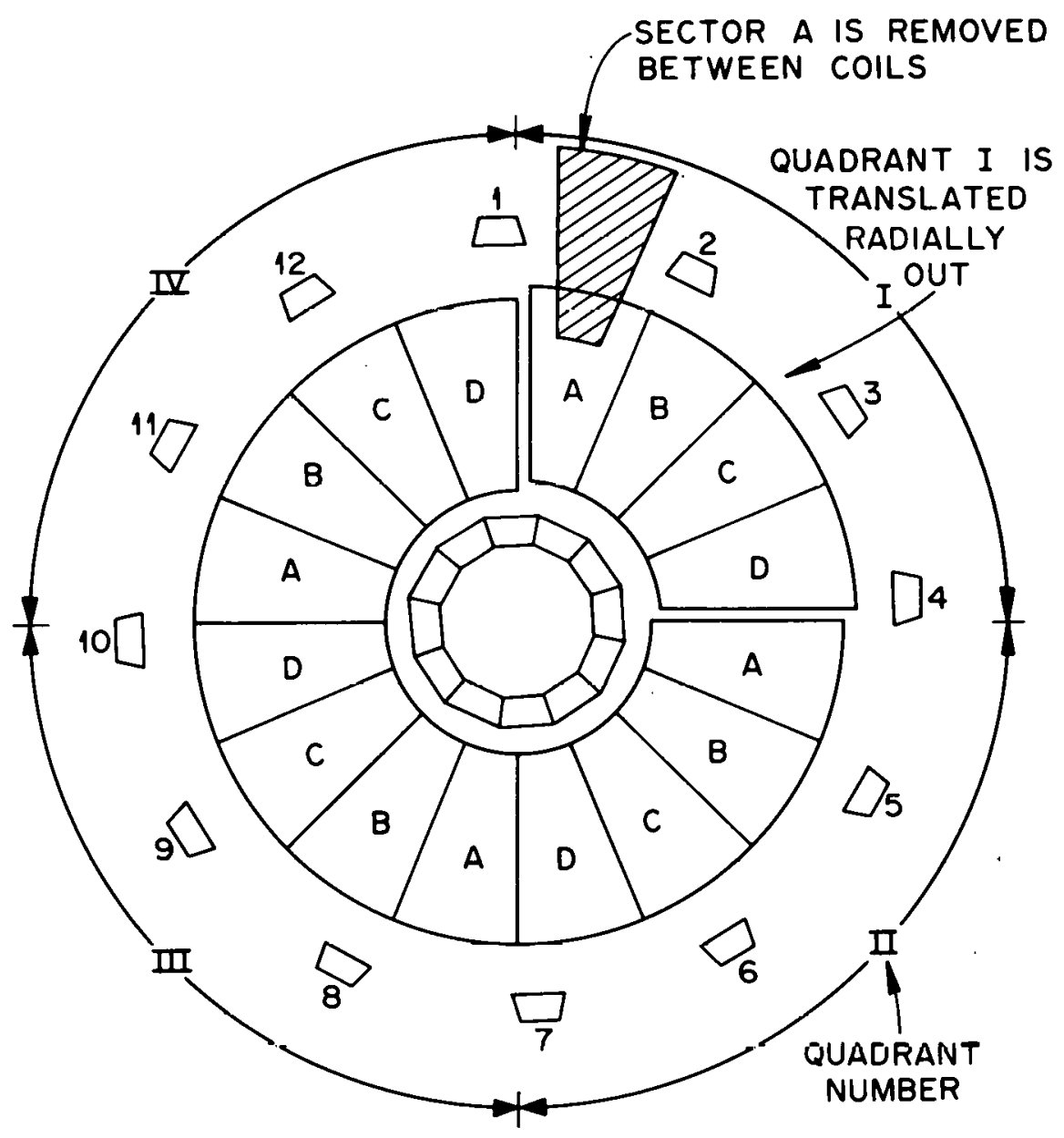

SECTOR

A

REMOVAL PROCEDURE

B

REMOVE BETWEEN COILS 182

REMOVE SECTOR A, THEN REMOVE

B BETWEEN COILS 1 \& 2

C

REMOVE SECTOR A; ROTATE B INTO

SPACE VACATED BY A; REMOVE C

BETWEEN COILS $2 \& 3$

D

$$
\text { REMOVE SECTOR A, OF QUADRANT II }
$$

REMOVE D BETWEEN COILS 4 \& 5

Fig. 4.7. Sector replacement procedure. 
cantilever spring. The slots are sealed either by an overlapping spring or by a flexible member bonded in place.

\subsubsection{Seal Integrity Requirements}

To determine the seal integrity required, the effects of torus outleakage and inleakage must be identified and allowable leak rates established. Seal integrity may then be stated in terms of the allowable gap between the seal and its contact surface. Numerous conditions contribute to the occurrence of seal gaps; they include thermal distortions, radiation swelling, and entrapment of particles beneath the seal. The latter condition is highly probable because assembly and disassembly of the device are performed by remotely operated equipment.

Torus outleakage results in an accumulation of tritium within the reactor cell. In-cell tritium concentration is directly proportional to torus outleakage rate and inversely proportional to the speed of the cell vacuum pumps (which collect and store the tritium), assuming no cold trapping surfaces within the cell.

Assuming an allowable $\mathrm{T}_{2}$ concentration of $40 \mu \mathrm{Ci} / \mathrm{m}^{3}$ within the cell, a cell pump speed of $2 \times 10^{5}$ liter/sec and a tritium pressure within the torus of $2.5 \times 10^{-5}$ torr (time averaged), the allowable seal conductance as calculated in Appendix $\mathrm{E}$ is 96 1iter/sec. If a seal gap height of $1 \mathrm{~mm}$ is assumed, the allowable length of seal gap is $275 \mathrm{~cm}$ or $1.15 \%$ of the entire seal length. Note that conductance increases directly as gap length and as the square of gap height; hence, under the above conditions, a gap of $0.1 \mathrm{~mm}$ can be tolerated over the entire seal length.

Torus inleakage results in increased load to the torus vacuum pumps and divertor. It is a function of reactor cell pressure as well as seal gap. In sect. 6 , it is shown that reactor cell pressure must be $10^{-4}$ torr maximum to satisfy electrical system requirements and that torus inleakage based on this pressure and the above determined seal gap is within acceptable limits.

Thus, the seal integrity required is determined by torus outleakage effects only, and the maximum acceptable seal conductance (for tritium) is 96 liter/sec. 


\section{MAINTAINABILITY CONSIDERATIONS}

The purpose of this section is to examine maintenance characteristics of the TNS Reference Design and to determine constraints imposed by the vacuum building.

\subsection{MAINTENANCE MODES - VACUUM VS ATMOSPHERIC}

Maintenance tasks will be performed with the reactor cell at base pressure $\left(10^{-4}\right.$ torr) whenever the tasks are within the capacity of vacuum-rated remote maintenance system (RMS) equipment and cannot be performed more efficiently at atmospheric pressure. The alternative is to repressurize the cell and use atmospheric RMS equipment. The time penalty for pressure cycling the cell is ten hours; two hours to vent, six hours to pump down, and two hours to bake out the plasma chamber. Each time the cell is vented, the plasma chamber is filled with an inert gas to equalize pressure across the torus joint seals; hence, the need for bake out.

Vacuum-rated RMS equipment will have lower speed, load capacity, and dexterity than similar atmospheric equipment. For a given task, there is a trade-off between time saved by use of the more efficient atmospheric RMS equipment vs time spent for pressure cycling the cell. The trade-off is complicated by the fact that some tasks can be performed in parallel with tokamak operations; that is, they do not require reactor shutdown. Examples are operation of shut-off valves to regenerate cryopumps, adjustment of diagnostic equipment, and coolant line leak checks. If it is elected to perform such tasks at atmospheric pressure, the time penalty incurred is ten hours plus total length of time needed to perform the task. It is evident that tasks that fall into this category should be pertormed in vacuum when possible, to avoid unnecessary reactor shutdown, and that the RMS equipment necessary should be available. 


\subsection{VACUUM-RATED REMOTE MAINTENANCE SYSTEM EQUIPMENT}

The array of vacuum-rated equipment will include two mobile servomanipulator units, a vehicle mounted unit for maintenance operations from floor level up to the torus midplane, and a bridge mounted unit for maintenance of upper levels of the cell. The tool array will include portable TV cameras, leak probes, and general purpose devices such as impact wrenches.

Vacuum-rated equipment requires special design provisions for heat dissipation, lubrication, and prevention of vacuum fusing. Actuators must be hermetically sealed and electrical conductors must be adequately spaced and specially insulated to prevent arc-over. There are numerous problems to contend with in designing vacuum-rated equipment; however, experience gained in recent space programs, such as the shuttle manipulator system and the flying teleoperator, shows that adequate solutions are available. ${ }^{7,8}$ The main questions are at what cost and with what compromise in performance.

\subsection{NONVACUUM-RATED REMOTE MAINTENANCE SYSTEM EQUIPMENT}

The majority of RMS equipment will be operated only at atmospheric pressure. This includes sector replacement modules, coil replacement modules, and transport units for beam lines and fuel injectors.

Two mobile manipulator units designed for atmospheric operation are required. They will be more efficient to operate than their vacuumrated counterparts and have greater accessibility in close quarters because of the compactness and greater power-to-weight ratio that are possible.

\subsection{SCHEDULED MAINTENANCE PERIODS}

Regularly scheduled maintenance operations that cannot be performed economically in vacuum will be performed during planned shutdown periods with the reactor cell at atmospheric pressure. Components will be designed for compatibility of maintenance schedules to assure efficient 
use of shutdown periods. Also, where possible, redundancy will be provided to reduce the frequency of unscheduled repairs.

\subsection{MAINTENANCE DURING SHAKEDOWN PHASE}

During the first two years of operation, or the shakedown phase, TNS will operate with hydrogen and thus remain nonradioactive. ${ }^{9}$ With an atmospheric pressure reactor cell, maintenance during this period would be performed "hands-on." However, with the vacuum building manned entry is not possible. In addition to the possibility of using remote maintenance during the shakedown phase, two alternate maintenance modes were considered: use of space-suited maintenance personnel and use of temporary torus joint seals to allow TNS operation with atmospheric pressure.

The first alternative is technically possible. Recent developments in technology have resulted in relatively high mobility for space-suited personnel, and high reliability of equipment. However, this mode has the following drawbacks. 10

(1) Personnel would require extensive training in the use of equipment.

(2) The equipment is designed for use in a low gravity environment and at one "g" results in rapid operator fatigue.

(3) Special safety measures would be required: either capability for rapid repressurization of the cell, or standby rescue equipment in case of personnel disablement.

The second alternative, temporary seals, is both technically feasible and economically attractive. The estimated cost of fabricating, installing, and subsequently removing the temporary seals is approximately $\$ 0.4$ million. The time required to remove the seals is approximately one month, and this task can be conducted in parallel with the numerous additional maintenance tasks that are required during the transition from hydrogen operation to D-T operation. 


\section{THIS PAGE}

\section{WAS INTENTIONALLY \\ LEFT BLANK}




\section{TECHNICAL FEASIBILITY}

This section examines various TNS systems to determine the requirements Imposed by a vacuum building design. Also, optimum base pressure for the reactor cell is determined.

\subsection{ELECTRICAL SYSTEMS}

Electrical systems within the vacuum enclosure require special design provision to prevent arc-over, corona, and other vacuum-electric effects. The problems of designing electrical systems for vacuum compatibility have been addressed in numerous space programs, and the technology that has developed is directly applicable to the vacuum building design.

Arc-over between two electric conductors is a function of the $-\circ$ pressure-distance product and the voltage difference between conductors. The Paschen curve (Fig. 6.1) shows the relation of arc-over voltage and pressure-distance for varfous gasses. Assuming that the range of interest for conductor spacing is between 1 and $10 \mathrm{~cm}$, a plot of arcover voltage vs pressure is made and appears in Fig. 6.2. The curves show the breakdown voltage for bare conductors. However, if insulation is added, the shape of the curves remains unchanged, but they are shifted upward to Indicate higher voltage levels.

Figure 6.2 also shows a low threshold for resistance to arc-over at pressures between 8 and $10^{-2}$ torr. Arc-over within this critical pressure range may occur between two bare conductors at $10^{3} \mathrm{kV}$. By avoiding cell pressures within this range and using proper insulation, the probability of arc-over is significantly reduced.

Deactivation of electrical systems is required whenever the cell pressure falls within this range, including during pumpdown and repressurization. It should be stressed, however, that insulation used on conductors must be of a grade which allows intermittent operation within this range without serious degradation so that local pressure fluctuations can be tolerated.

Another electrical phenomenon present in a vacuum environment is corona discharge. It occurs when an ionized layer of gas forms near a 


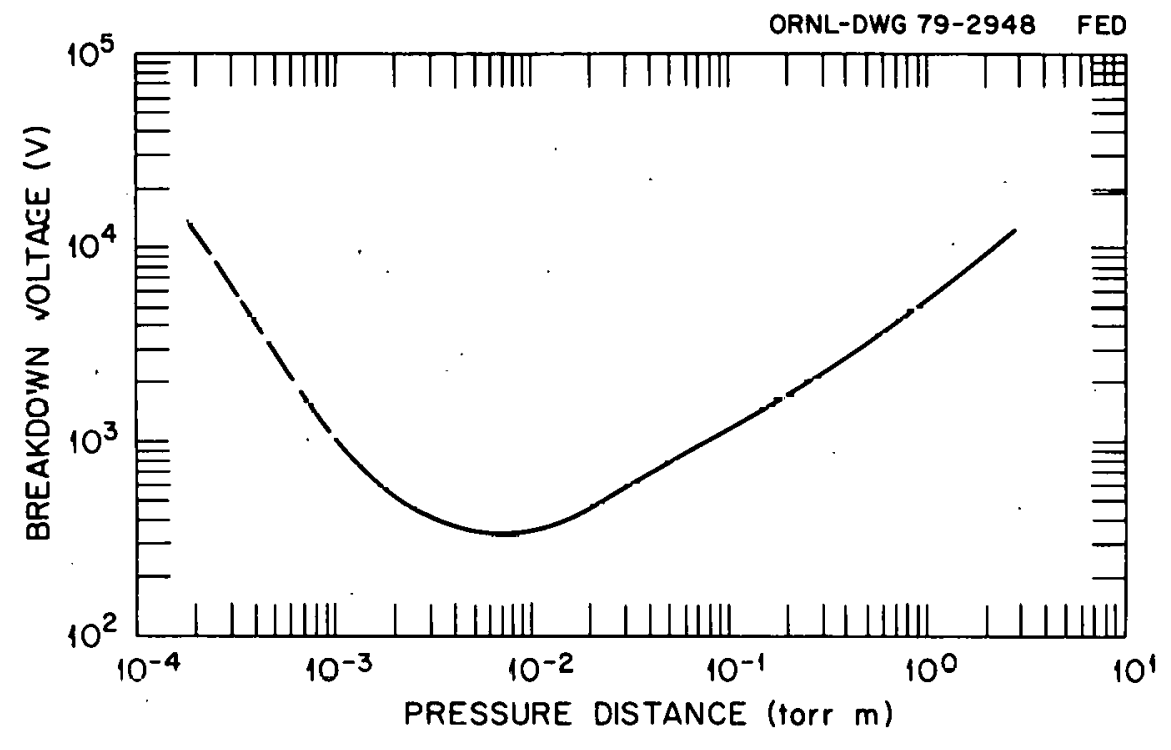

f'ig. b.1. Paschen curve. 
ORNL- DWG 79-2669

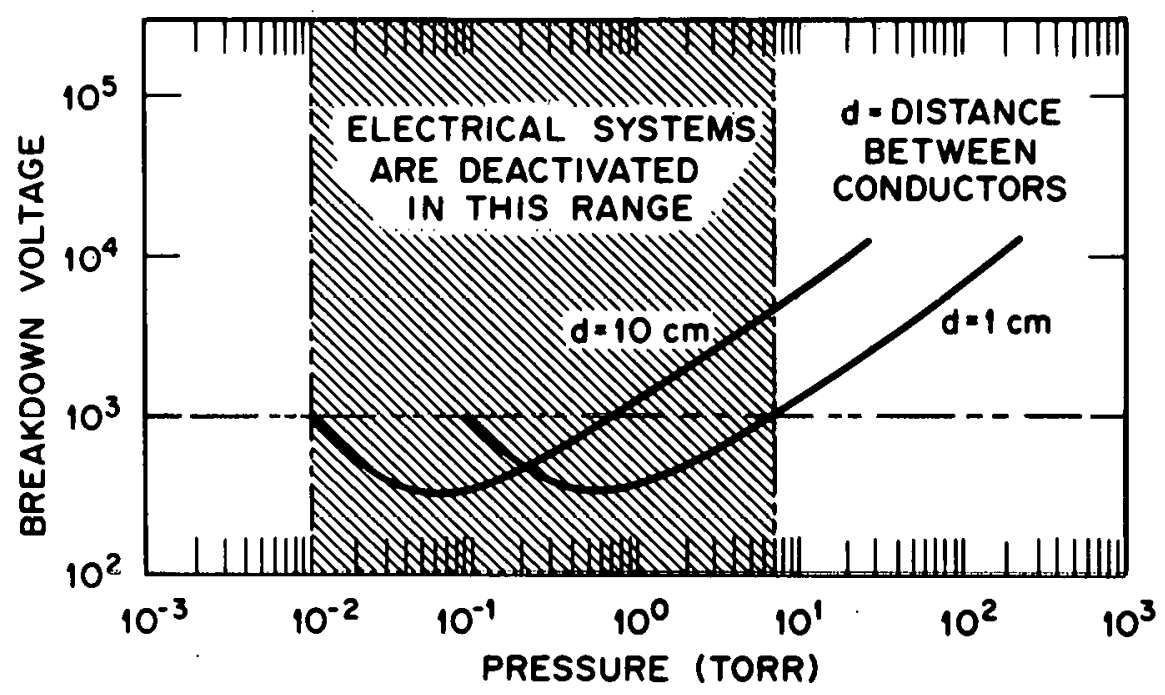

Fig. 6.2. Pressure dependence of dielectric strength of air. 
conductor and acts as a space charge. Corona discharge is initiated by pulsed currents flowing between a conductor and an ionized gas to create electromagnetic interference. Excessive heat is generated and, if allowed to continue, arc-over and deterioration of insulation will result.

Conditions leading to onset of corona are the presence of ionized gas and high voltages. Elimination of bare connectors within the vacuum building is a necessary, but not sufficient, safeguard against corona because insulation material itself can build up sufficient potential to initiate corona discharge. The most effective prevention of corona is the proper ues of grounding.

A third phenomenon of vacuum-electric systems is a complex group of occurrences combined under the general heading of cavitation. Essentially, this is a condition in which rapid pressure fluctuations cause arc-over and corona discharge to occur at lower-than-predicted voltages. For example, at a pressure of $10^{-4}$. torr, steady-state arc-over voltage is $10^{5} \mathrm{~V} / \mathrm{cm}$. If a pressure fluctuation of $10^{-6}$ torr $/ \mathrm{sec}$ is present, arcover may occur at 1.0 to 1.5 orders of magnitude less. 11

The onset of arc-over, corona, and cavitation can be minimized in the vacuum building by use of an interleaved grounding system which reduces conductor-to-conductor voltages. This entails breaking up into several low voltage power supply elements the total operating voltage required and interleaving (alternating) with elements composed of equal series inductance. ${ }^{12}$ For example, the $\mathrm{OH}$ circuit requires a maximum operating voltage of $59.38 \mathrm{kV}$, which can be realized with 15 power supply elements at $4 \mathrm{~V}$, each interleaved with 15 coil sections of equal series inductance. By so doing, the fault potential, and therefore the insulation rating, is four times the interleaved value (12 kV); without interleaving, the fault potential and insulation rating would be three times $59.38 \mathrm{kV}$, or approximately $180 \mathrm{kV}$.

Neutral beam injectors and $r f$ heating units require an electrical power supply of 150 and $100 \mathrm{kV}$, respectively. An interleaved ground system is not applicable because of the high ground-to-peak voltage requirement and to prevent arc-over, sealed and pressurized junction boxes are required. 
In summary, the successful operation of electrical equipment within the reactor cell depends on the avoidance of the critical pressure range, maintaining low peak voltages by use of interleaved ground systems, providing sealed and pressurized junction boxes for high voltage service lines, and using conductor insulation that is resistant to the effects of arc-over, corona, and cavitation.

\subsection{TRITIUM CONSIDERATIONS}

In Sect. 4 of this report, it was arbitrarily assumed that the in-cell tritium concentration is $40 \mu \mathrm{Ci} / \mathrm{m}^{3}$, a condition which occurs at a torus joint conductance of 96 11ter/sec and a cell pump speed of $2 \times$ $10^{5}$ liter/sec. This permitted us to estimate the degree of "tightness" required for the seals and thus determine feasibility of the design.

Although the assumed $T_{2}$ concentration is representative of values used in fusion reactors where breathability is a factor, its justification for TNS remains to be established. A possible justification is that, by maintaining a breathable level, isolation of the cell from maintenance areas is not required during atmospheric pressure operation. However, this too requires further study to determine if desorption of $\mathrm{T}_{2}$ from cell surfaces affects $\mathrm{T}_{2}$ concentration levels when the cell is repressurized.

Based on the above assumptions, the flow rate of tritium out of the torus and into the collection system is $2.4 \times 10^{-3}$ torr 1 iter $/ \mathrm{sec}$ or $746 \mathrm{Ci} /$ day, and the amount of tritium suspended within the cell is

$3.2 \mathrm{Ci}$ (see Appendix E).

There are many factors that must be considered and resolved to determine the full impact of a vacuum building design on tritium systems. They include:

(1) rate of tritium absorption on in-cell surfaces when the cell is evacuated;

(2) rate of $T_{2}$ desorption when the cell is brought up to atmospheric pressure; 
(3) identification of gasses released into the cell to determine if any gas component tends to sorb on surfaces and affect tritium retention capability;

(4) decontamination procedure required prior to removal of equipment from the cell; and

(5) air detritiation requirement, if any, when the cell is repressurized for maintenance.

With presently available information, some tritium aspects of the vacuum building can be defined and are clearly advantagenus. They are:

(1) The criclum rèleasè to the environment via permeation through reactor cell walls is considerably reduced because of the low pressure.

(2) The double walls of the vacuum building provide redundancy in the event of accidental $\mathrm{T}_{2}$ release. As a result, it may be possible to eliminate redundant enclosure of in-cell components that contain tritium.

(3) If an accidental $\mathrm{T}_{2}$ release occurs within the cell while the cell is at vacuum, cleanup is effected by operation of the high vacuum pumps. This results in a low mass accumulation and hence low detritiation cost.

(4) If an accidental $\mathrm{T}_{2}$ release occurs when the cell is at atmospheric pressure, cleanup may be effected by cell pumpdown resulting in a relatively rapid (six hour) cleanup time.

(5) The tendency to form tritiated water (HTO) is reduced because of the low pressure and, therefore, less water vapor present in the vacuum building.

\subsection{DEWARS}

The function of a dewar is to minimize gas conduction heat load to the cryogenic surfaces by maintaining a high vacuum. Since a high vacuum is maintained within the entire reactor cell, it is theoretically possible to eliminate the TF coil dewars, thereby simplifying the design and reducing device assembly/disassembly time. However, there are numerous disadvantages from an operational and reliabillty viewpoint. 
(1) When the reactor cell is brought to atmospheric pressure, the TF coil temperature will increase due to gas conduction heat loads. The time required to recool the coils is between two and six days depending on refrigeration capacity and effectiveness of coolant distribution within the coils. Since cell repressurization is necessary for numerous maintenance operations, the additional downtime seriously affects plant availability.

(2) During cell repressurization, hydrogen will desorb from cryogenic surfaces and mix with incoming air to form an explosive gas mixture. This necessitates use of explosion-proof equipment throughout the cell, or use of an inert gas for cell repressurization.

(3) During cell pumpdown, the reactor cell pressure must be synchronized with the TF coil temperature to avoid excessive particle buildup on cryogenic surfaces, which would degrade their thermal properties.

(4) Tritium releases into the reactor cell will be cold-trapped by the cryogenic surfaces rather than collected and stored by the in-cell pumps. The potential accumulation can be large enough to impact tritium availability for the fuel cycle. Also, desorption during cell repressurization may result in a high concentration level and require a very long air detritiation cycle.

(5) A sudden release of gasses into the cell due to leakage of a coolant. line may result in a local pressure rise sufficient to quench the TF coils.

In view of the above, it is concluded that $T F$ coils should be retained within the vacuum building.

Although TF coil dewars will be retained, there is the possibility of simplifying their construction, and hence simplifying device assembly/ disassembly, by using mechanically assembled rather than welded dewar joints. The resultant decrease in vacuum tightness will have negligible effect when the reactor cell is evacuated. However, when the cell is at atmospheric pressure, inleakage will occur. Depending on the length of time that the cell remains at atmospheric pressure, the inleakage rate, and permissible accumulation of particles on cryogenic surfaces, it may be possible to operate the device for several maintenance periods before 
a surface reconditioning cycle is required. Surface conditioning consists of warmup to $\mathrm{LN}_{2}$ temperature and pumpout of desorbed gasses.

In order to assess the cost vs benefits of mechanically assembled dewars, additional effort is required to define the dewar structure, TF coil refrigeration requirements, and the frequency of conditioning cycles. Hence, mechanically assembled dewars are considered a design option, and welded dewars are assumed for the Reference Design.

\subsection{BASE PRESSURE OF A VACUUM BUILDING}

The reactor cell pressure must be selected to satisfy two conditions; it must be below the critical range for electrical systems and, since torus inleakage varies directly with cell pressure, it must be sufficiently low to maintain inleakage within acceptable limits.

The torus vacuum pumping system (TVPS) is required to remove postburn gasses within $25 \mathrm{sec}$ after each pulse, and inleakage will increase the pump speed necessary to meet this requirement. ${ }^{13}$

The relation of inleakage to pump speed is calculated in Appendix $F$ and shown graphically in Fig. 6.3. The torus inleakage rate that corresponds to a cell pressure of $10^{-4}$ torr and seal conductance of 96 liter/ sec (conditions imposed by electrical and tritium systems) is shown and clearly indicates that further reduction of cell pressure and inleakage rate is not warranted.

In performing the inleakage calculations, it was assumed that the primary gasses within the cell are hydrogenic and are pumped by the cryoadsorption panels. If the cell gasses are primarily nitrogen (a distinct possibility in view of the numerous $\mathrm{LN}_{2}$ coolant lines within the cell and the probability of air leakage into the cell), then torus inleakage will be pumped by the $\mathrm{LN}_{2}$ thermal shield rather than the cryoadsorption panel, and TVPS requirements are completely independent of inleakage rate.

An additional effect of torus inleakage is the introduction of impurities which must be removed by the divertor. In operation, the divertor scrapes away the outer surfaces of the plasma at a rate of $3 x$ $10^{23}$ particles/sec. ${ }^{14}$ Assuming a seal conductance of 96 liter $/ \mathrm{sec}$ 


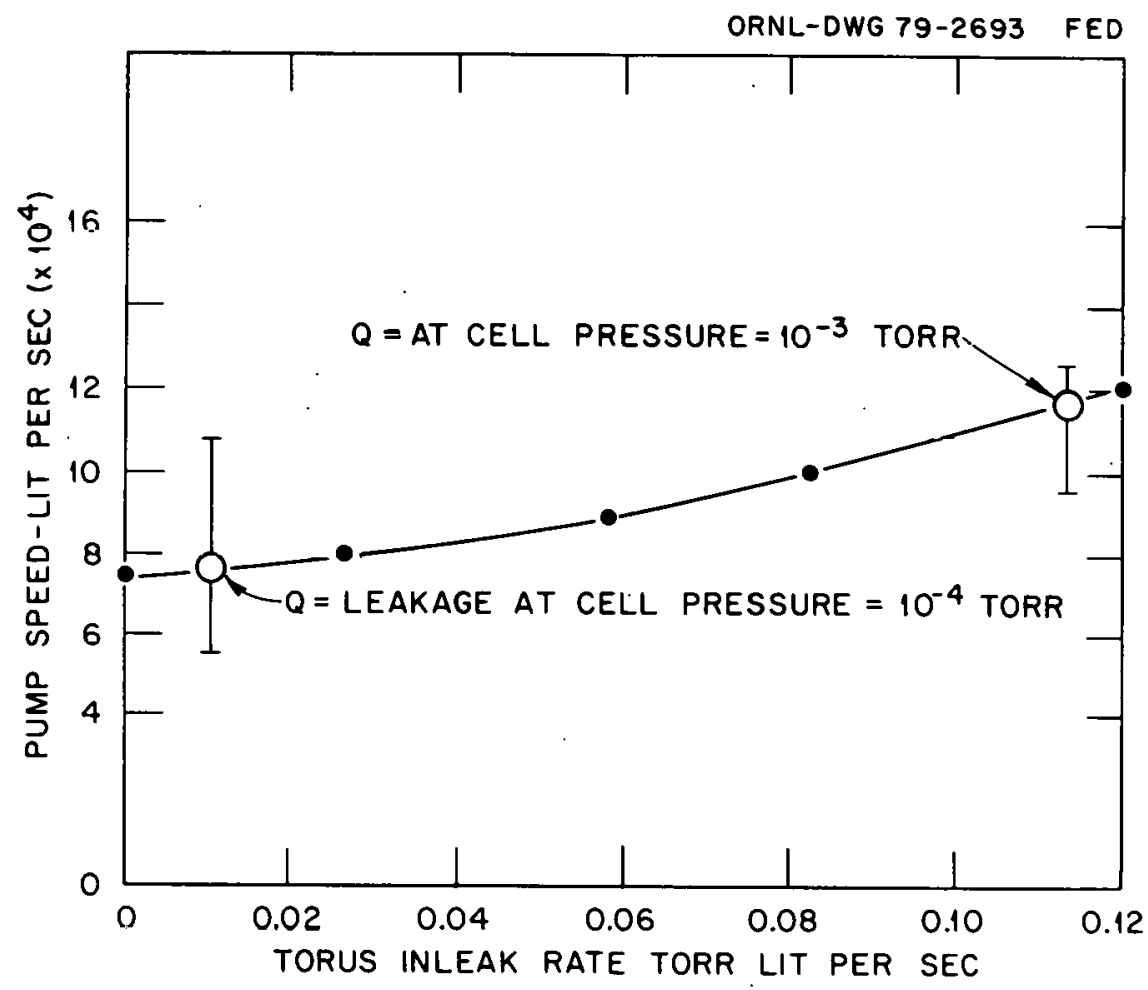

Flg. 6.J. Effect of toruc inleakage nn pump speed required. 
and cell pressure of $10^{-4}$ torr, torus inleakage adds impurities at this outer layer of $3 \times 10^{19}$ particles/sec, or $0.01 \%$ of the scrape-off rate. In view of this low ratio, it is assumed that divertor requirements are not impacted by inleakage. However, further study is needed to identify the specific composition of in-cell gasses and determine if the presence of any particular species is detrimental to divertor operation. 


\section{EFFECT ON PLANT AVAILABILITY}

The most important benefit of a vacuum building configuration is the ability to replace torus sectors with relative ease and safety. The full potential of this benefit cannot be assessed for TNS because sector replacement is not a scheduled maintenance item. However, in a CPR, the blanket must be replaced on a regularly scheduled basis, and the value of rapid sector replacement can be readily quantified in terms of plant availability.

\subsection{VACUUM BUILDING COMMERCIAL POWER REACTOR}

In order to calculate plant availability of a vacuum building CPR, we assume a device having the same basic design as TNS (as described in Sect. 4), but with the following additions and exceptions.

(1) Blanket modules as described in Ref. 15 are used instead of first wall panels (see Fig. 7.1).

(2) Each torus sector has six service lines: two for blanket coolant, two for shield coolant, and two for lithium breeding. Because leak-tightness of pressurized lines is of paramount importance within the vacuum building, ali service lines are joined by welding.

(3) During maintenance operations the reactor cell is filled with an inert gas to avoid the fire hazard created by lithium exposure to a1r. (A possible alternative is to sever the lithium lines and cap their ends prior to cell repressurization.)

Plant availability is based on the following assumptions:

(1) A four-year blanket life.

(2) Annual shutdown to replace a $25 \%$ fraction of the blanket. Other scheduled maintenance is performed in parallel with blanket changeout during this shutdown.

(3) A three-shift, 20-hr workday during annual shutdown.

(4) Unscheduled outages during the year amounting to $5 \%$ of blanket changeout time. 


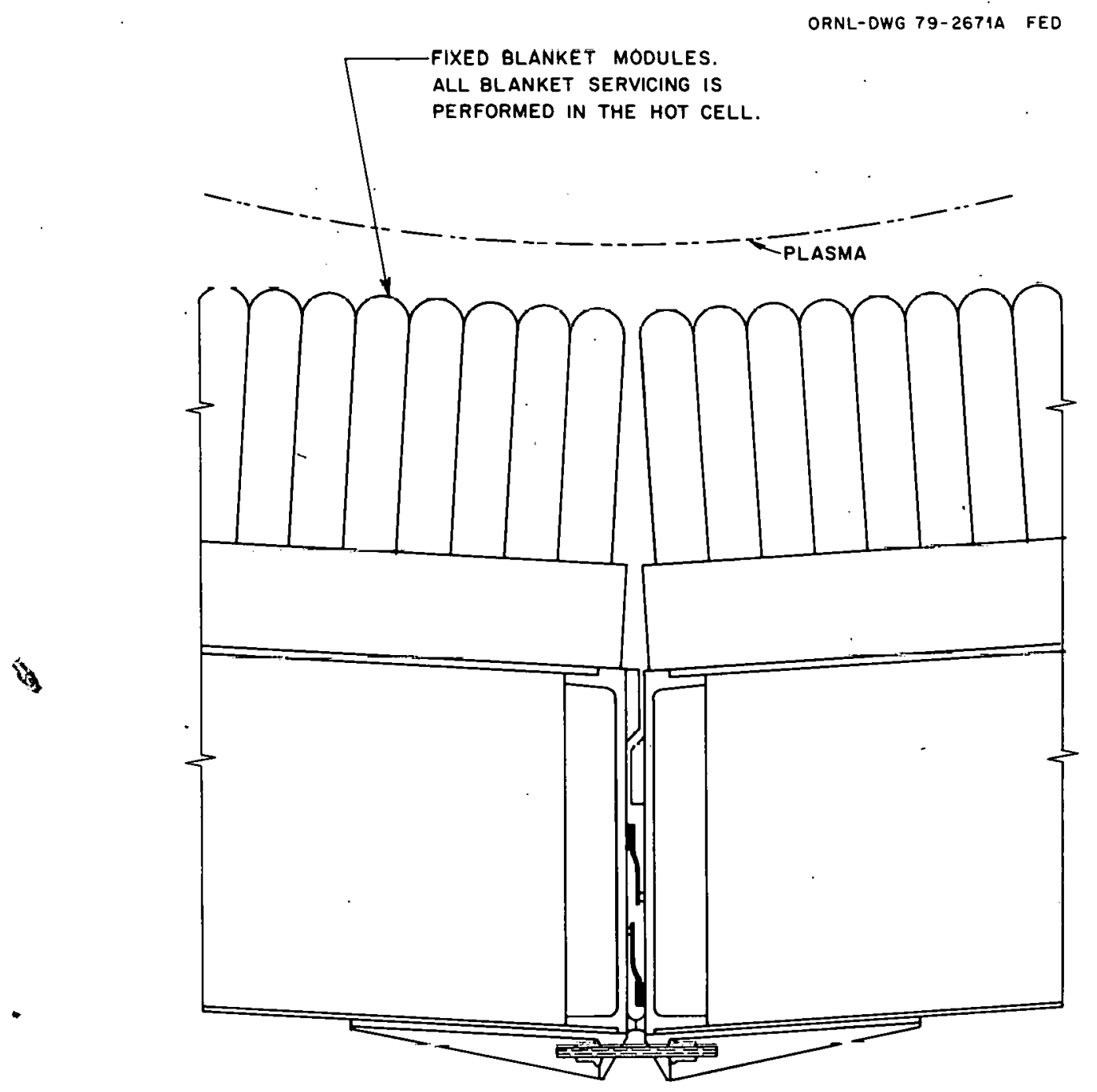

Fig. 7.1. Detail of torun joint CPR: bolted. 
(5) All maintenance tasks are performed by remote means. Whenever feasible, tasks are conducted in parallel; unlimited crew and equipment availability is assumed.

(6) Blanket replacement consists of an exchange of torus sectors; the replaced sector is refurbished in the maintenance cell during reactor operation.

A detailed breakdown of sector replacement tasks is shown in Appendix A; time estimates are given for each task. In order to provide a reasonable degree of accuracy, highly repetitive tasks are broken down to definitive subtasks and a time estimate made for each subtask.

As shown in Appendix A, the total time required for blanket changeout is $1238.5 \mathrm{hr}$. Assuming an additional 5\% downtime for unplanned outages and a 20-hr workday, the annual plant shutdown time is 60 days and plant availability is $82.2 \%$.

\subsection{ATMOSPHERIC BUILDING COMMERCIAL POWER REACTOR}

The atmospheric building CPR is assumed to have the same basic design features as TNS except as follows.

(1) The torus sectors are joined by a continuous weld at the inner wall. Sector attachment bolts, as used in the Reference Design, are retained with the welded torus and used for preweld alignment (see Fig. 7.2).

(2) Each torus sector has six service lines. However, since leaktightness is less critical, the lines are joined with mechanical clamps rather than by welding.

(3) As with the vacuum building CPR, blanket modules are used instead of the first wall panels. However, the portions of the blanket that cover the torus welds are demountable (see Fig. 7.2) in order to provide access for cutting and rewelding. There are eight demountable modules per torus joint, each measuring approximately $1.0 \mathrm{~m}$ wide by $2.5 \mathrm{~m}$ long.

(4) The reactor cell is filled with an inert gas during maintenance shutdown. 
ORNL-DWG T9-267IB FED

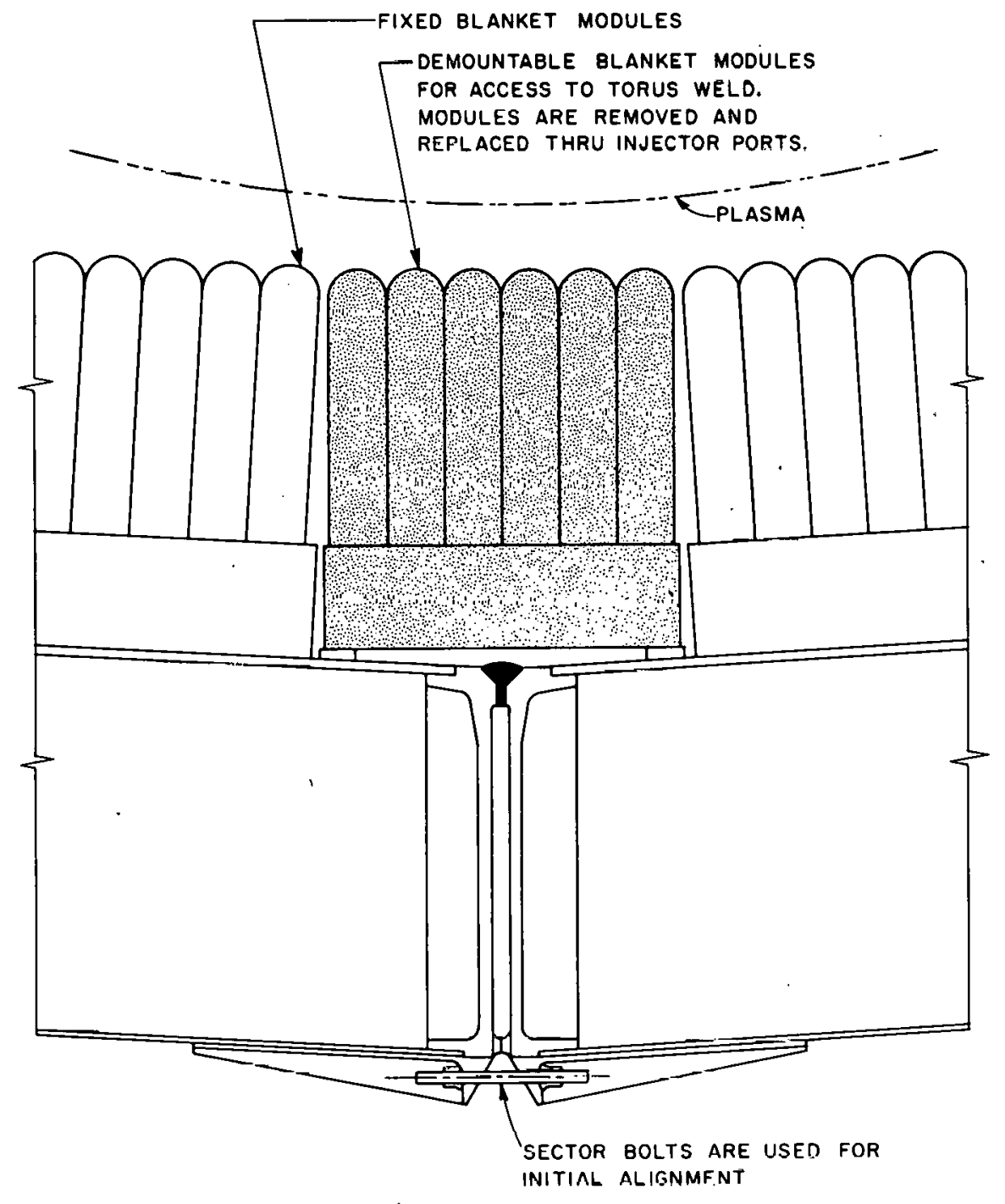

fig. 7.2. Detall of Lorus joint CPR: welded. 
The tasks required for blanket changeout of the atmospheric building CPR are shown in Appendix B. The total elapsed time is $2768 \mathrm{hr}$, giving a plant availability of $60.2 \%$.

Since actual values of plant availability depend on numerous considerations in addition to those addressed, the above values have relative significance only and indicate the increase in plant availability due to use of a vacuum building configuration.

\subsection{RISK OF OPERATIONS}

A significant advantage of the vacuum building CPR is the relatively low risk incurred during a torus sector replacement. The welded torus used with an atmospheric pressure CPR requires insertion of complex mechanical equipment into the torus, which, if failure occurs, will necessitate a lengthy retrieval operation. In contrast, the bolted torus used with a vacuum building CPR uses externally mounted equipment, which, if failure occurs, can be readily retrieved and replaced. 


\section{THIS PAGE \\ WAS INTENTIONALLY \\ LEFT BLANK}




\section{8. $\operatorname{cosT}$ VS BENEFITS}

In Sect. 4, the cost penalty for a vacuum building TNS was identified as $\$ 20.5$ million. This, however, accounted only for the containment building and the cell vacuum pump system.

There are many additional factors to be considered before a true TNS cost penalty can be determined, and, although these factors cannot be quantified at present, they are listed here for reference.

(1) Factors that may increase the cost penalty of the vacuum building configuration are:

- Cost of two mobile servomanipulator units for in-vacuum operation.

- Cost of electrical, hydraulic, and pneumatic penetrations through the metallic chamber of the reactor cell.

- Cost to fabricate and install the temporary seals for shakedown operations and to remove the seals prior to D-T operation.

- Installation costs for the cell vacuum pumps including pumproom, electrical power and cooling water distribution to each pump, $\mathrm{LN}_{2}$ supply to pump traps, piping for isolation valves, and spare pump units.

- Higher detritiation costs due to higher tritium release rate into the cell.

(2) Factors that may decrease the cost penalty of the vacuum buflding configuration are:

- Elimination of in-vessel RMS equipment. Units eliminated include a cutter-welder module, an in-vessel manipulator with mobility system, a transport module for inserting and removing equipment from the torus, and a leak-check unit.

- Possible elimination of the emergency air collection system by using. the cell vacuum pumps to collect accidental release of tritium.

For the purpose of this study it is assumed that the above cost factors cancel each other and that the cost penalty for a vacuum build1ng TNS is $\$ 20.5$ million. 
The main benefit to TNS of the vacuum building configuration is a reduction in the time required to replace torus sectors. The time required to replace one torus sector is $675.5 \mathrm{hr}$ for the vacuum building TNS and $2282.5 \mathrm{hr}$ for an atmospheric building TNS (see Appendixes C and $D)$. Assuming a three-shift, 20-hr workday, this results in a downtime of 34 days for the vacuum building TNS and 114 days for the atmospheric building TNS. If a $\$ 4$ million per month cost penalty is assumed for plant downtime (a reasonable assumption in view of the $\$ 510$ million capital cost for TNS), a cost saving of

$$
\frac{\$ 4 \text { million }}{\text { month }} \times \frac{(114-34)}{30} \text { months }=\$ 10.6 \text { million }
$$

is realized each time a sector is replaced, and the $\$ 20.5$ million cost penalty for a vacuum building is recovered after two sector replacements. 


\section{CONCLUSIONS AND RECOMMENDATIONS}

\subsection{CONCLUSIONS}

1. The vacuum building was selected as the preferred SVE concept. Its selection was based largely on the ability to replace torus sectors without dismantling the SVE structure - a characteristic that results in low downtime and high reliability.

2. Technical feasibility of the vacuum building configuration has been shown. An investigation of its impact on mafor TNS systems shows that designing for vacuum compatibility can be achieved with existing technology.

3. The vacuum building can be pumped down rapidly, and at acceptable cost, thus minimizing the downtime required to perform maintenance operations at atmospheric pressure.

4. The downtime required to replace the blanket of a CPR is reduced by $56 \%$ with the vacuum building configuration, and the task is performed at relatively low risk. This results in comparative plant availability values of $60.2 \%$ for an atmospheric building CPR and $82.2 \%$ for a vacuum building CPR.

5. The cost penalty for a TNS vacuum building is approximately $\$ 20.5$ million.

\subsection{RECOMMENDATIONS}

1. Further study of tritium systems is required to establish allowable tritium concentration within the reactor cell, to determine the effects of tritium adsorption on in-cell surfaces, and to establish the rate of tritium desorption when the cell is at atmospheric pressure.

2. In view of the close rating between the bell jar and the vacuum building concepts, the following additional study is recommended.

(1) A preliminary design of the bell jar structure to permit quantitative comparison with the vacuum building concept on the basis of downtime required for the replacement of a sector. 
(2) A design study of vacuum-rated maintenance equipment to determine speed and dexterity capabilities and therefore the extent that maintenance operations can be performed in vacuum. 
APPENDIX A

MAINTENANCE TASKS AND TIME ESTIMATES TO REPLACE SECTORS OF A VACUUM BUILDING COMMERCIAL POWER REACTOR

This section identifies the maintenance tasks required to replace the blanket of a SVE-configured CPR. A time estimate is given for each task, and the total time required to replace $25 \%$ of the blanket is indicated.

All maintenance tasks are performed with remotely operable equipment. The major RMS units and the functions of each are:

(1) Sector replacement module (SRM) - disconnects a sector from its adjacent module, removes it from the torus, and transports it to the maintenance cell.

(2) Injector transport module (ITM) - disconnects service lines to the NBI and cryopump unit and transports them to the maintenance cell.

(3) Pipe cutter-welder module (PCWM) - cuts and welds the sector service Iines.

(4) Bridge-mounted manipulator (BMM) - performs general purpose tasks above the device midplane.

(5) Floor-mounted manipulator (FMM) - performs general purpose tasks below the device midplane.

Abbreviations used in the following tables are:

$\mathrm{RC}$ = reactor cell

$\mathrm{MC}=$ maintenance cell

$\mathrm{TJ}=$ torus joint

NBI = neutral beam injector

$\mathrm{CP}$ = cryopump

A description of the CPR design appears in Sect. 7 of this report. A maintenance task that is conducted in parallel with other tasks is denoted (*) and the time required for its performance is not included in the total elapsed time.

A maintenance task for which a detailed task breakdown is available is denoted $(t)$. 
APPENDIX A

CPR (Bolted torus)

Task: Replace blanket in quadrant I

\begin{tabular}{|c|c|c|}
\hline Task & Activity & Time estimate \\
\hline 1.0 & Shut down & 3.0 \\
\hline 2.0 & Prepare quadrant I for sector replacement & 336.5 \\
\hline 3.0 & Replace sectors in quadrant I & 232.0 \\
\hline 4.0 & Restore quadrant I to operational status & 636.0 \\
\hline 5.0 & start up & 31.0 \\
\hline \multicolumn{2}{|c|}{ Total } & 1238.5 \\
\hline
\end{tabular}

At $20 \mathrm{hr} /$ day $=\frac{1238.5}{20}=61.9$ days

CPR (Bolted torus)

Task 1.0 Shut down

\begin{tabular}{|c|c|c|}
\hline $\begin{array}{l}\text { Subtask } \\
\text { number }\end{array}$ & Açtivitè̃ & TIme eslluale \\
\hline 1.. .1 & Discharge coils & $0.5^{*}$ \\
\hline 1.02 & $\begin{array}{l}\text { Drain coolant from quadrant. I } \\
\text { (blanket and shield coolant) }\end{array}$ & 3.0 \\
\hline 1.03 & Repressurlize realió cell & $2.0^{*}$ \\
\hline 1.04 & Repressurize torus with inert gas & $\underline{2.0^{*}}$ \\
\hline Tot & & 3.0 \\
\hline
\end{tabular}


APPENDIX A

CPR (Bolted torus)

Task 2.0 Prepare quadrant I for sector replacement

\begin{tabular}{|c|c|c|}
\hline $\begin{array}{l}\text { Subtask } \\
\text { number }\end{array}$ & Activity & $\begin{array}{l}\text { Time } \\
\text { estimate }\end{array}$ \\
\hline 2.01 & Deflate seal and open $\mathrm{RC}$ hatch & 0.5 \\
\hline 2.02 & $\begin{array}{l}\text { Prepare work area for maintenance operation - } \\
\text { bring in service lines - set up view } \\
\text { systems, etc. }\end{array}$ & 6.0 \\
\hline 2.03 & $\begin{array}{l}\text { Remove two NBI/CP units and stow (duct flanges } \\
\text { are quick-disconnect type) (ITM) }\end{array}$ & 42.0 \\
\hline 2.04 & $\begin{array}{l}\text { Disconnect shield coolant lines to sector A } \\
\text { (two lines; welded joints; two cuts per line; } \\
\text { remove and stow a section of line) (PCWM) }\end{array}$ & 20.0 \\
\hline 2.05 & Repeat 2.04 for blanket coolant lines & 20.0 \\
\hline 2.06 & Repeat 2.04 for $\mathrm{Li}$ lines & 20.0 \\
\hline 2.07 & Disconnect diagnostic bundle to sector A (FMM) & 12.0 \\
\hline $2.08<$ & Repeat 2.04 through 2.07 for sectors $B, C$, and D & 216.0 \\
\hline 2.09 & Translate PF coils to stow position (BMM, FMM) & $48.0^{*}$ \\
\hline Total & & 336.5 \\
\hline
\end{tabular}


APPENDIX A

CPR (Bolted torus)

Task 3.0 Remove and replace sectors in quadrant I

\begin{tabular}{|c|c|c|}
\hline $\begin{array}{l}\text { Subtask } \\
\text { number }\end{array}$ & Activity & $\begin{array}{l}\text { 'Time } \\
\text { estimate }\end{array}$ \\
\hline 3.01 & Transport SRM to RC (station 1-2) & 4.0 \\
\hline 3.02 & $\begin{array}{l}\text { Remove sector bolts at } \mathrm{AD} \text { and } \mathrm{DA} \text { (six bolts } \\
\text { plus one repositioning } \mathrm{SRM} \text { to station } 3-4 \text { ) }\end{array}$ & 14.0 \\
\hline 3.03 & $\begin{array}{c}\text { Disconnect quadrant I lateral locks and translate } \\
\text { quadrant I radially out to stop position (FMM) }\end{array}$ & $12.0^{*}$ \\
\hline 3.04 & $\begin{array}{l}\text { Remove sector } A \text {; transport to } M C \text {; return SRM } \\
\text { to } \mathrm{RC}\end{array}$ & $23.0^{\dagger}$ \\
\hline 3.05 & Repeat 3.04 for sectors $B, C$, and D & 69.0 \\
\hline 3.06 & Transport new sector $\mathrm{D}$ into $\mathrm{RC}$ and install & 23.0 \\
\hline 3.07 & Repeat 3.06 for sectors $C, B$, and $A$ & 69.0 \\
\hline 3.08 & $\begin{array}{l}\text { Translate quadrant I radially in and install } \\
\text { lateral locks }\end{array}$ & 12.0 \\
\hline 3.09 & $\begin{array}{l}\text { Install sector bolts at } \mathrm{DA} \text { and } \mathrm{AD} \text { (repositioning } \\
\text { of SRM required) }\end{array}$ & 18.0 \\
\hline 3.10 & Conduct leak test of $\mathrm{TJ}$ seals & $12.0^{*}$ \\
\hline 3.11 & Transport SRM to $\mathrm{MC}$ & $4.0^{*}$ \\
\hline \multicolumn{2}{|c|}{ Total } & 232.0 \\
\hline
\end{tabular}


APPENDIX A

CPR (Bolted torus)

\begin{tabular}{|c|c|c|}
\hline & Remove sector A & \\
\hline $\begin{array}{l}\text { Subtask } \\
\text { number }\end{array}$ & Activity & $\begin{array}{l}\text { Time } \\
\text { estimate }\end{array}$ \\
\hline 3.04 .01 & Extend locks from SRM to ground & 0.5 \\
\hline 3.04 .02 & Remove three sector bolts from $\mathrm{TJ} A \mathrm{AD}$ & 6.0 \\
\hline 3.04 .03 & $\begin{array}{l}\text { Extend SRM rails and lock to torus support } \\
\text { structure }\end{array}$ & 0.5 \\
\hline 3.04 .04 & $\begin{array}{l}\text { Remove sector-to-rall bolts (one upper and } \\
\text { one lower) }\end{array}$ & 2.0 \\
\hline 3.04 .05 & $\begin{array}{l}\text { Extend carriage from SRM to sector } A \text { and } \\
\text { lock to sector }\end{array}$ & 0.5 \\
\hline 3.04 .06 & $\begin{array}{l}\text { Jack up sector A - transfer weight to } \\
\text { carriage }\end{array}$ & 1.0 \\
\hline 3.04 .07 & $\begin{array}{l}\text { Translate sector A tangentially } \approx 10 \mathrm{~cm} \text { to } \\
\text { clear shadow shields }\end{array}$ & 0.5 \\
\hline 3.04 .08 & Translate sector A radially out - into SRM & 1.0 \\
\hline 3.04 .09 & Retract SRM rails & 0.5 \\
\hline 3.04 .10 & Retract SRM ground locks & 0.5 \\
\hline 3.04 .11 & Transport SRM to MC & 4.0 \\
\hline 3.04 .12 & Offload sector A & 2.0 \\
\hline 3.04 .13 & $\begin{array}{l}\text { Transport SRM to } \mathrm{RC} \text { and position for next } \\
\text { sector removal }\end{array}$ & 4.0 \\
\hline Total & & 23.0 \\
\hline
\end{tabular}


APPENDIX A

CPR (Bolted torus)

\begin{tabular}{|c|c|c|}
\hline & Task 4.0 Restore quadrant I to operational & tatus \\
\hline $\begin{array}{l}\text { Subtask } \\
\text { number }\end{array}$ & Activity & Time estimate \\
\hline 4.01 & Translate PF coils to operation position & $48.0^{*}$ \\
\hline 4.02 & $\begin{array}{l}\text { Install shield coolant lines on } \\
\text { sectors } A, B, C \text {, and } D\end{array}$ & 160.0 \\
\hline 4.03 & $\begin{array}{l}\text { Inetall blanket coolant lines on } \\
\text { sectors A, B, C, and D }\end{array}$ & $\cdot 160.0$ \\
\hline 4.04 & Install Li lines on sectors $A, B, C$, and $D$ & 160.0 \\
\hline 4.05 & $\begin{array}{l}\text { Install diagnostic bundles on sectors } A \text {, } \\
B, C \text {, and } D\end{array}$ & 48.0 \\
\hline 4.06 & Install two NBI/CP units & 108.0 \\
\hline \multicolumn{2}{|c|}{ Total } & 636.0 \\
\hline
\end{tabular}

CPR (Bolted torus)

Task 5.0 Startup

\begin{tabular}{llc}
\hline $\begin{array}{c}\text { Subtask } \\
\text { number }\end{array}$ & \multicolumn{1}{c}{ Activity } & Time estimate \\
\hline 5.01 & Close RC hatch and inflate seal & 1.0 \\
5.02 & Pump down the RC & 6.0 \\
5.03 & Charge TF coils & $0.5^{*}$ \\
5.04 & Fill coolant 1ines (shield and blanket) & $3.0^{*}$ \\
5.05 & Activate NBIs & $6.0^{*}$ \\
5.06 & Activate torus vacuum pumps & $6.0^{*}$ \\
5.07 & Operate divertor to remove impurities & $\frac{24.0}{31.0}$ \\
\hline
\end{tabular}




\section{APPENDIX B}

\section{MAINTENANCE TASKS AND TIME ESTIMATES TO REPLACE SECTORS OF A NONVACUUM BUILDING COMMERCIAL POWER REACTOR}

This section identifies the maintenance tasks required to replace the blanket of a non-SVE configured CPR. A time estimate is given for each task, and the total time required to replace $25 \%$ of the blanket is indicated.

All maintenance tasks are performed with remotely operable equipment. The major RMS units and the functions of each are:

(1) Sector replace module (SRM) - disconnects a sector from its adjacent module, removes it from the torus, and transports it to the maintenance cell.

(2) Injector transport module (ITM) - disconnects service lines to the NBI and cryopump unit and transports them to the maintenance ce11.

(3) Pipe clamp module (PCM) - clamps/unclamps sector service lines.

(4) Bridge-mounted manipulator (BMM) - performs general purpose tasks above the device midplane.

(5) Floor-mounted manipulator (FMM) - performs general purpose tasks below the device midplane.

(6) In-vessel manipulator (IVM) - general purpose tasks within the torus.

(7) Module conveyor unit (MCU) - removes modules from the torus, through an injector port, and deposits them in a storage rack.

(8) Cutter-welder machine (CWM) - cuts and rewelds the torus joint.

A description of the CPR design appears in Sect. 7 of this report.

A maintenance task that is conducted in parallel with other tasks is denoted (*) and the time required for its performance is not included in the total elapsed time.

A maintenance task for which a detailed task breakdown is available is denoted $(t)$. Abbreviations used are explained in Appendix A. 
APPENDIX B

CPR (Welded torus)

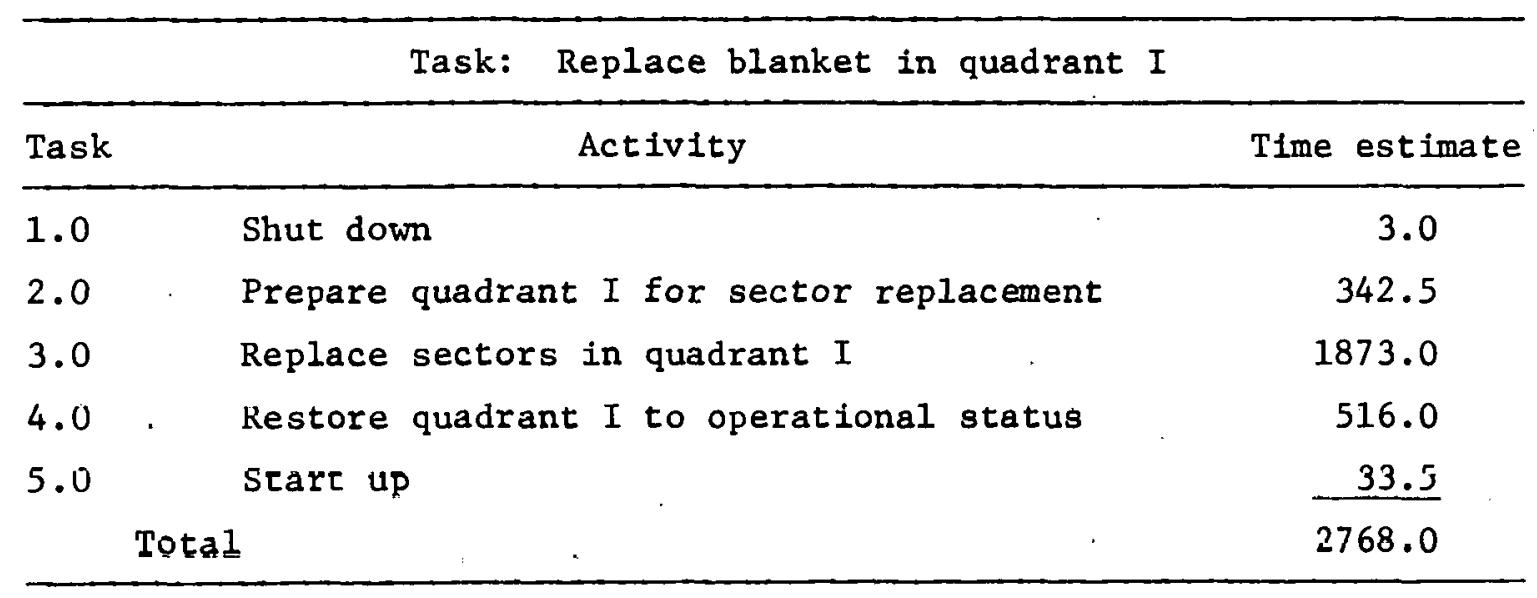

At $20 \mathrm{hr} /$ day $=138.4$ days

CPR (Welded torus)

Task 1.0. Shutdown

\begin{tabular}{llc}
\hline $\begin{array}{l}\text { Subtask } \\
\text { number }\end{array}$ & Activity & l'ime cotimatć \\
\hline 1.01 & Discharge coils & $0.5^{*}$ \\
1.02 & Drain coolant lines in quadrant I & $\frac{3.0}{3.0}$ \\
Total & & \\
\hline
\end{tabular}


APPENDIX B

CPR (Welded torus)

Task 2.0 Prepare quadrant I for sector replacement

\begin{tabular}{|c|c|c|}
\hline $\begin{array}{l}\text { Subtask } \\
\text { number }\end{array}$ & Activity & Time estimate \\
\hline 2.01 & Open hatch & 0.5 \\
\hline 2.02 & $\begin{array}{l}\text { Prepare RC for maintenance operation: } \\
\text { set up TV system, electrical and } \\
\text { pneumatic lines, etc. }\end{array}$ & 6.0 \\
\hline 2.03 & $\begin{array}{l}\text { Remove two NBI/CP units and stow within } \\
\text { RC (nonquick disconnect type duct } \\
\text { connections) }\end{array}$ & 56.0 \\
\hline 2.04 & $\begin{array}{l}\text { Remove access plate on injector ports } \\
\text { of sectors C and D }\end{array}$ & 24.0 \\
\hline 2.05 & $\begin{array}{l}\text { Disconnect and remove blanket coolant } \\
\text { line to sectors } A, B, C \text {, and } D \text {. } \\
\text { Total = eight lines; mechanical } \\
\text { assessment joints }\end{array}$ & 80.0 \\
\hline 2.06 & $\begin{array}{l}\text { Repeat } 2.05 \text { for shield coolant } 1 \text { ines and } \\
\text { Li lines }\end{array}$ & 160.0 \\
\hline 2.07 & $\begin{array}{l}\text { Disconnect diagnostic bundle; sectors } \\
\text { A, B, C, and D }\end{array}$ & 16.0 \\
\hline 2.08 & Translate PF coils to stow position & $48.0^{*}$ \\
\hline L. घy & $\begin{array}{l}\text { Iuslall tiedown rods botween toris and } \\
\text { external structure to preserve } \\
\text { alignment during cut-weld operations }\end{array}$ & $48.0^{*}$ \\
\hline Total & . & 342.5 \\
\hline
\end{tabular}


APPENDIX B

CPR (Welded torus)

Task 3.0 Remove and replace sectors in quadrant I

\begin{tabular}{|c|c|c|}
\hline $\begin{array}{l}\text { Subtask } \\
\text { number }\end{array}$ & Activity & Time estimate \\
\hline 3.01 & $\begin{array}{l}\text { Remove blanket modules to uncover } T J \text { welds } \\
\text { (five TJs, eight blanket modules per TJ) }\end{array}$ & $472.0^{\dagger}$ \\
\hline 3.02 & Cut TJs (five places) & $148.0^{\dagger}$ \\
\hline 3.03 & $\begin{array}{l}\text { Remove sector bolts (five TJs, three bolts } \\
\text { per TJ); requires 3RM iepusilluning two } \\
\text { times }\end{array}$ & 36.0 \\
\hline 3.04 & $\begin{array}{l}\text { Translate quadrant I out to stop } \\
\text { position }\end{array}$ & 8.0 \\
\hline 3.05 & $\begin{array}{l}\text { Remove sector } A \text {; transport to } M C \text {, offload, } \\
\text { return SRM to RC }\end{array}$ & $26.0^{\dagger}$ \\
\hline 3.06 & Repeat 3.05 for sectors $B, C$, and D & $78.0^{\dagger}$ \\
\hline 3.07 & $\begin{array}{l}\text { Prepare surface of sector D (quadrant IV) } \\
\text { for welding (machine to required } \\
\text { flatness) }\end{array}$ & 22.0 \\
\hline 3.08 & $\begin{array}{l}\text { Repeat } 3.07 \text { for surface of sector } A \\
\quad \text { (quadrant II) }\end{array}$ & 22.0 \\
\hline 3.09 & Transport new sector D Lo RC and Install & $26.00^{\dagger}$ \\
\hline 3.10 & Repeat 3.09 for sectors $C, B$, and $A$ & $78.0^{\dagger}$ \\
\hline 3.11 & Install sector bolts at $T J, A B, B C$, and $C D$ & 22.0 \\
\hline 3.12 & $\begin{array}{l}\text { Translate quadrant I radially in } \\
\text { (to stops) }\end{array}$ & $\dot{8} . U$ \\
\hline 3.13 & Install sector bolts $\mathrm{DA}$ and $\mathrm{AD}$ & $14.0^{*}$ \\
\hline 3.14 & $\begin{array}{l}\text { Weld TJs DA through } \mathrm{AD} \text { (five welds) (TJ } \\
\text { welding time }=1.8 \times \mathrm{TJ} \text { cutting time) }\end{array}$ & 266.0 \\
\hline 3.13 & $\begin{array}{l}\text { Install blanket modules that straddle } \mathrm{TJ} \\
\text { wclds (flve places); note blanket module; } \\
\text { install time equation }=1.4 \times \text { removal time }\end{array}$ & 661.0 \\
\hline Total & & 1873.0 \\
\hline
\end{tabular}

${ }^{\dagger}$ Similar to task 3.04 of Appendix A. 


\section{APPENDIX B}

CPR (Welded torus)

Task 3.01 Remove blanket modules to uncover welds

\begin{tabular}{|c|c|c|}
\hline $\begin{array}{l}\text { Subtask } \\
\text { number }\end{array}$ & Activity & Time estimate \\
\hline 3.01 .01 & Transport IVM-1 to RC station $1-2$ & 3.0 \\
\hline 3.01 .02 & Transport $\mathrm{MCU}-1$ to $\mathrm{RC}$ station $1-3$ & 3.0 \\
\hline 3.01 .03 & $\begin{array}{l}\text { Insert IVM-1 into torus and prepare for } \\
\text { maintenance operation at } \mathrm{TJ} A D\end{array}$ & 4.0 \\
\hline 3.01 .04 & $\begin{array}{l}\text { Cut coolant line blanket module } 1 \text {; remove } \\
\text { section of line and stow }\end{array}$ & 2.0 \\
\hline 3.01 .05 & $\begin{array}{l}\text { Repeat } 3.01 .04 \text { for three more lines of } \\
\text { blanket module (each blanket module has } \\
\text { two coolant lines and two Li lines) }\end{array}$ & 6.0 \\
\hline 3.01 .06 & Retool IVM-1 for bolt removal & 1.5 \\
\hline 3.01 .07 & $\begin{array}{l}\text { Remove eight mounting bolts from blanket } \\
\text { module and stow }\end{array}$ & 4.0 \\
\hline 3.01 .08 & Retool IVM-1 for blanket module egress & 1.5 \\
\hline 3.01 .09 & Remove blanket module; place on $\mathrm{MCU}$ & 2.0 \\
\hline 3.01 .10 & $\begin{array}{l}\text { Remove blanket module from torus; stow } \\
\text { on MCU rack }\end{array}$ & $2.0^{*}$ \\
\hline 3.01 .11 & Retool IVM-1 for pipe cutting operation & 1.5 \\
\hline 3.01 .12 & $\begin{array}{l}\text { Repeat } 3.01 .04 \text { through } 3.01 .11 \text { for Llit } \\
\text { remaining seven blanket modules DF } \\
\text { T.J AD }\end{array}$ & 129.5 \\
\hline 3.01 .13 & Relocatc IVM-1 from TJ AD to T.T AB & 2.0 \\
\hline 3.01 .14 & $\begin{array}{l}\text { Repeat } 3.01 .04 \text { through } 3.01 .12 \text { for eight } \\
\text { blanket modules DF 'IJ AB }\end{array}$ & 148.0 \\
\hline 3.01 .15 & $\begin{array}{l}\text { Remove IVM-1 from torus and into its } \\
\text { transport module }\end{array}$ & 2.0 \\
\hline 3.01 .16 & Transport IVM-1 to station $2-3$ & 2.0 \\
\hline 3.01 .17 & Relocate MCU-1 to station $1-2$ & 2.0 \\
\hline 3.01 .18 & $\begin{array}{l}\text { Repeat } 3.01 .03 \text { to } 3.01 .12 \text { for eight } \\
\text { blanket modules of } \mathrm{TJ} \mathrm{AB}\end{array}$ & 152.0 \\
\hline 3.01 .19 & Remove I.VM-1 from torus & 2.0 \\
\hline 3.01 .20 & $\begin{array}{l}\text { Transport IVM-2 to RC station } 3-4 \text { and set } \\
\text { up for operation at } \mathrm{TJ} C D\end{array}$ & $2.0^{*}$ \\
\hline
\end{tabular}


APPENDIX B

Task 3.01 (continued)

\begin{tabular}{|c|c|c|}
\hline $\begin{array}{l}\text { Subtask } \\
\text { number }\end{array}$ & Activity & Time estimate \\
\hline 3.01 .21 & Transport MCU-2 to RC station $2-3$ & $2.0^{*}$ \\
\hline 3.01 .22 & $\begin{array}{l}\text { Repeat } 3.01 .04 \text { through } 3.01 .12 \text { to remove } \\
\text { five blanket modules from } \mathrm{TJ} \mathrm{CD}\end{array}$ & $152.0^{*}$ \\
\hline 3.01 .23 & Relocate IVM-2 for operation at TJ D & $2.0^{*}$ \\
\hline 3.01 .24 & $\begin{array}{l}\text { Repeat } 3.01 .04 \text { through } 3.01 .12 \text { to remove } \\
\text { eight blanket modules from T.T na }\end{array}$ & $152.0^{*}$ \\
\hline 3.01 .25 & Retract IVM-2 from torus & $2.0^{*}$ \\
\hline 3.01 .26 & Transport IVM-I and IVM-2 to MC & 4.0 \\
\hline 3.01 .27 & Transport $M C U-1$ and $M C U-2$ to $M C$ & $1.0^{*}$ \\
\hline Total & & 472.0 \\
\hline
\end{tabular}


APPENDIX B

CPR (Welded torus)

Task 3.02 Cut torus joints in quadrant $I$

\begin{tabular}{|c|c|c|}
\hline $\begin{array}{l}\text { Subtask } \\
\text { number }\end{array}$ & Activity & Time estimate \\
\hline 3.02 .01 & Transport CWM to RC station $1-2$ & 4.0 \\
\hline 3.02 .02 & $\begin{array}{l}\text { Insert CWM into torus and set up for work } \\
\text { on } T J A D\end{array}$ & 6.0 \\
\hline 3.02 .03 & $\begin{array}{l}\text { Cut } \mathrm{TJ} A D \text { : Note cutting speed is } 15 \text { in./ } \\
\text { min; two cuts required; a 4-hr tool } \\
\text { change is required between cuts }\end{array}$ & 18.0 \\
\hline 3.02 .04 & Relocate CWM for work on $\mathrm{TJ} A B$ & 4.0 \\
\hline 3.02 .05 & Repeat 3.02 .03 for $\mathrm{TJ} A B$ & 18.0 \\
\hline 3.02 .06 & Remove CWM from torus & 6.0 \\
\hline 3.02 .07 & Relocate CWM to station $2-3$ & 2.0 \\
\hline 3.02 .08 & Repeat 3.02 .02 and 3.02 .03 for $\mathrm{TJ} B C$ & 24.0 \\
\hline 3.02 .09 & Remove CWM from torus & 4.0 \\
\hline 3.02 .10 & Relocate CWM to station $3-4$ & 4.0 \\
\hline 3.02 .11 & $\begin{array}{l}\text { Repeat } 3.02 .11 \text { through } 3.02 .06 \text { to cut } \mathrm{TJ} C D \\
\text { and } \mathrm{DA}\end{array}$ & 52.0 \\
\hline 3.02 .12 & Retract CWM from torus & 6.0 \\
\hline 3.02 .13 & Transport CWM to maintenance cell & $4.0^{*}$ \\
\hline Total & & 148.0 \\
\hline
\end{tabular}


APPENDIX B

CPR (Welded torus)

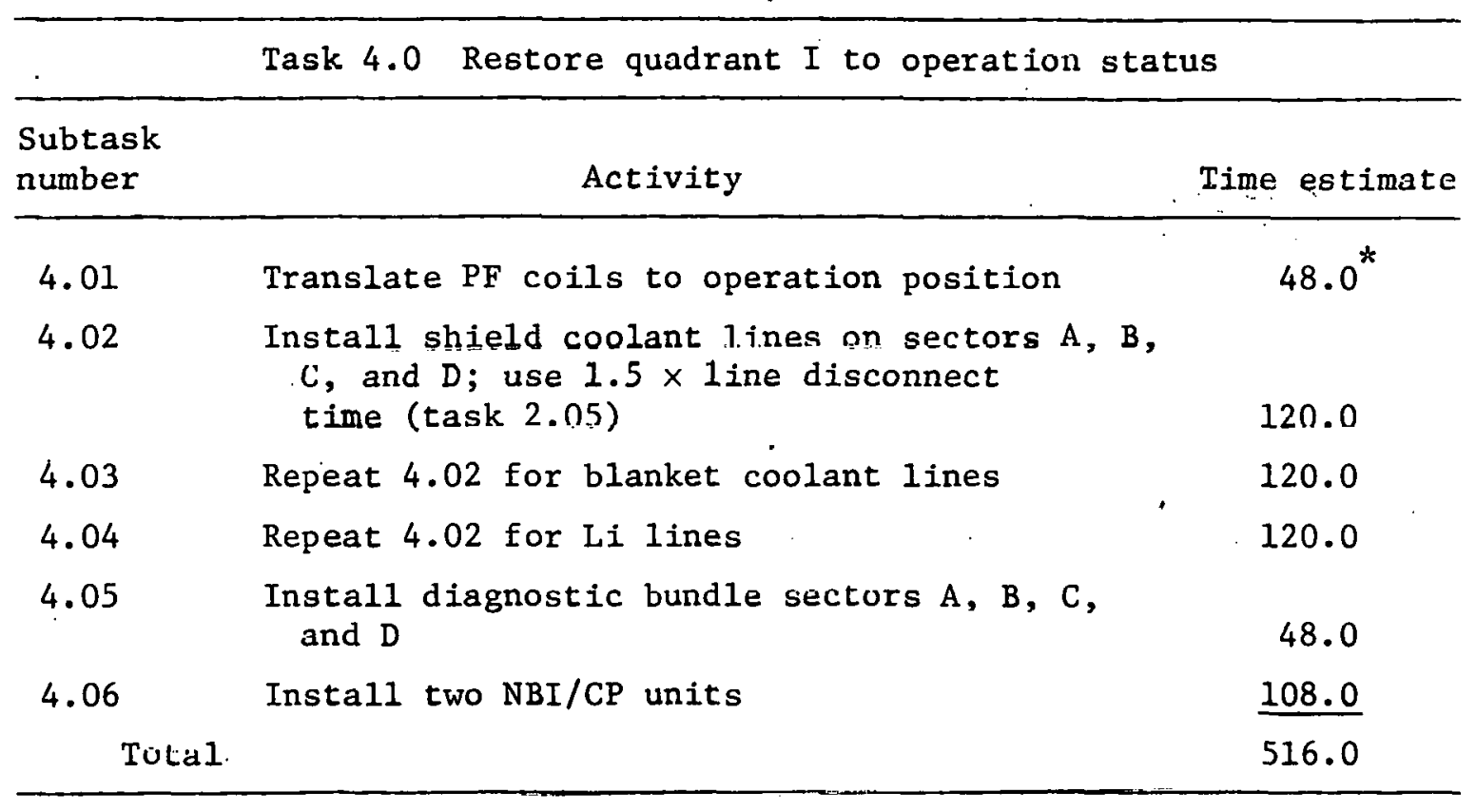

CPR (Welded torus)

\begin{tabular}{lll}
\hline \multicolumn{1}{c}{ Task 5.0 Startup } \\
$\begin{array}{l}\text { Subtask } \\
\text { number }\end{array}$ & \multicolumn{1}{c}{ Activity } & Time estimate \\
\hline 5.01 & Close RC hatch & 0.5 \\
5.02 & Charge TF colls & $0.5^{*}$ \\
5.03 & Fill coolant line (shield and blanket) & $3.0^{*}$ \\
5.04 & Activate NBI & $6.0^{*}$ \\
5.05 & Activate cryopumps in TVPS & 6.0 \\
5.06 & Operate divertor to remove impurities & 24.0 \\
5.07 & Leak check torus & $\frac{24.0^{*}}{33.5}$ \\
Total & & 3 \\
\hline
\end{tabular}




\begin{abstract}
APPENDIX C
MAINTENANCE TASKS AND TIME ESTIMATES TO REPLACE ONE SECTOR OF A TNS DEVICE HAVING A MECHANICALLY ASSEMBLED TORUS
\end{abstract}

This section identifies the maintenance tasks required to replace one torus sector of the TNS device which is described in Sect. 4. The unit being replaced is sector $B$ of quadrant. $I$. In order to remove sector B, sector A must first be removed and stowed. There are two NBI/CP units in quadrant $I$, and both must be removed to permit replacement of sector $B$.

All maintenance tasks are performed remotely and the estimated time for each task is given. The remote maintenance system (RMS) equipment used is identified in Appendix A.

A maintenance task that is conducted in parallel with other tasks is denoted $(*)$ and the time required for its performance is not included in the total elapsed time.

A maintenance task for which a detailed task breakdown is available is denoted $(t)$. Abbreviations used are explained in Appendix A.

TNS (Bolted torus)

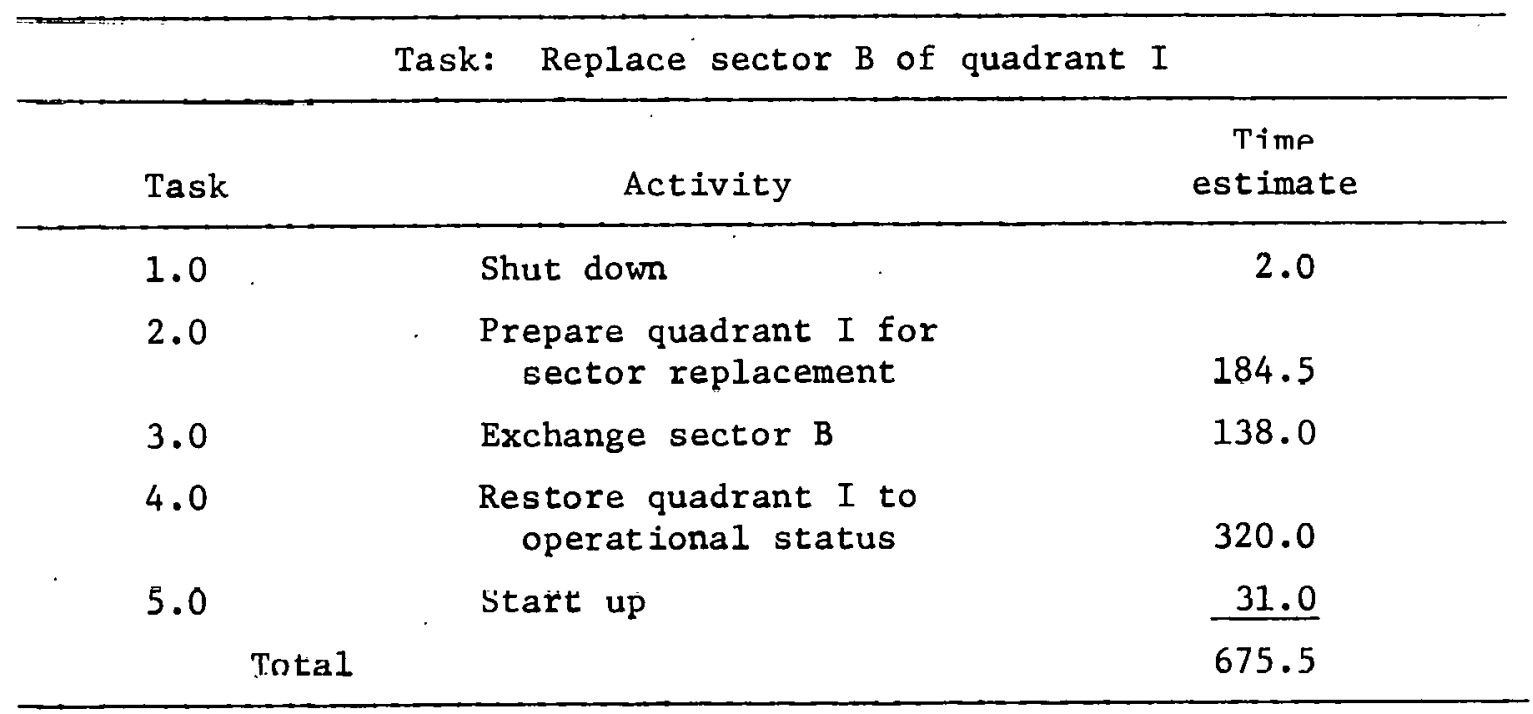


APPENDIX C

TNS (Bolted torus)

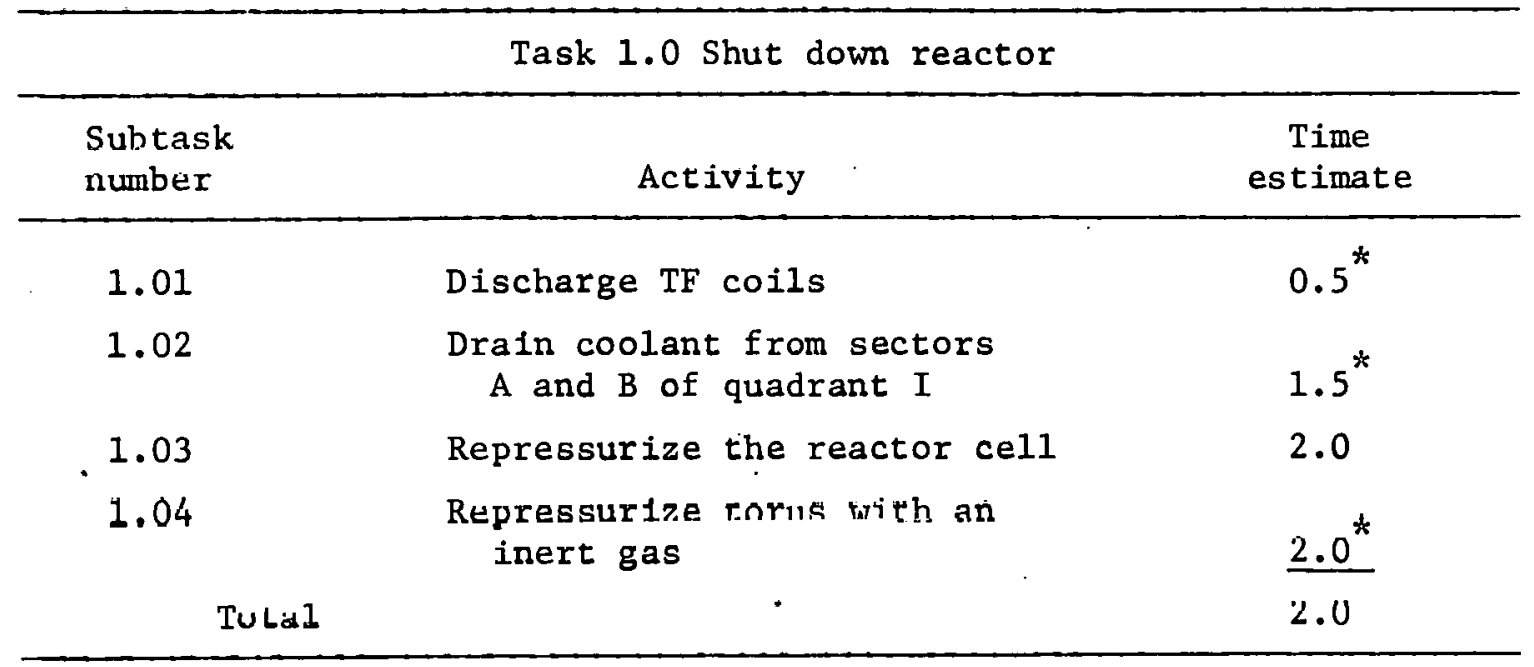

TNS (Bolted torus)

\begin{tabular}{|c|c|c|}
\hline $\begin{array}{l}\text { Subtask } \\
\text { number }\end{array}$ & Activity & $\begin{array}{c}\text { Time } \\
\text { estimate }\end{array}$ \\
\hline 2.01 & Deflate seal and open RC hatch & 0.5 \\
\hline 2.02 & $\begin{array}{l}\text { Prepare work area for maintenance } \\
\text { operation, bring in service lines, } \\
\text { set up viewing system }\end{array}$ & 6.0 \\
\hline 2.03 & $\begin{array}{l}\text { Remove two } N B I / C F \text { units and stow. } \\
\text { Note: duct flanges are quick } \\
\text { disconnect type }\end{array}$ & 42.0 \\
\hline 2.04 & $\begin{array}{l}\text { Disculliecl service lines to sectors } \\
\text { A and B. Total of eight lines, two } \\
\text { shield coolant lines, two FW coolant } \\
\text { lines. Note: lines are joined by } \\
\text { welding; each line must be cut in } \\
\text { two places and a section removed } \\
\text { and stowed }\end{array}$ & 120.0 \\
\hline 2.05 & $\begin{array}{l}\text { Disconnect diagnostic bundles to } \\
\text { sectors } A \text { and } B\end{array}$ & 16.0 \\
\hline \multirow[t]{2}{*}{2.06} & Translate PF coils to stow position & $48.0^{*}$ \\
\hline & & 184.45 \\
\hline
\end{tabular}


APPENDIX $C$

Task 3.0 Exchange sector $B$

\begin{tabular}{|c|c|c|}
\hline $\begin{array}{l}\text { Subtask } \\
\text { number }\end{array}$ & Activity & $\begin{array}{l}\text { Time } \\
\text { estimate }\end{array}$ \\
\hline 3.01 & Transport SRM to RC station $1-2$ & 4.0 \\
\hline 3.02 & $\begin{array}{l}\text { Remove three sector bolts at } \mathrm{AD} \text {; } \\
\text { reposition SRM to station } 3-4 ; \\
\text { remove three sector bolts at } \mathrm{DA}\end{array}$ & 14.0 \\
\hline 3.03 & $\begin{array}{l}\text { Disconnect quadrant I lateral } \\
\text { locks and translate quadrant I } \\
\text { radially out to its stop position }\end{array}$ & $12.0 *$ \\
\hline 3.04 & $\begin{array}{l}\text { Remove sector A and stow in RC (see } \\
\text { detailed task breakdown) }\end{array}$ & $21.0^{\dagger}$ \\
\hline 3.05 & $\begin{array}{l}\text { Remove sector } B \text { and transport } \\
\text { to maintenance cell }\end{array}$ & 23.0 \\
\hline 3.06 & $\begin{array}{l}\text { Transfort new sector } B \text { into } \mathrm{RC} \\
\text { and install }\end{array}$ & 24.0 \\
\hline 3.07 & Install sector $A$ & 22.0 \\
\hline 3.08 & $\begin{array}{l}\text { Translate quadrant I radially in } \\
\text { and install lateral locks }\end{array}$ & 12.0 \\
\hline 3.09 & $\begin{array}{l}\text { Install sector bolts at } \mathrm{TJ} \mathrm{DA} \text {; } \\
\text { reposition } \mathrm{SRM} \text { to station } 3-4 \\
\text { and install sector bolts at } \mathrm{TJ} A D\end{array}$ & 18.0 \\
\hline 3.10 & Conduct leak test of 'I'J seals & $12.0^{*}$ \\
\hline 3.11 & Transport SRM to maintenance cell & $4.0^{*}$ \\
\hline Total & . & 138.0 \\
\hline
\end{tabular}


APPENDIX C

TNS (Bolted torus)

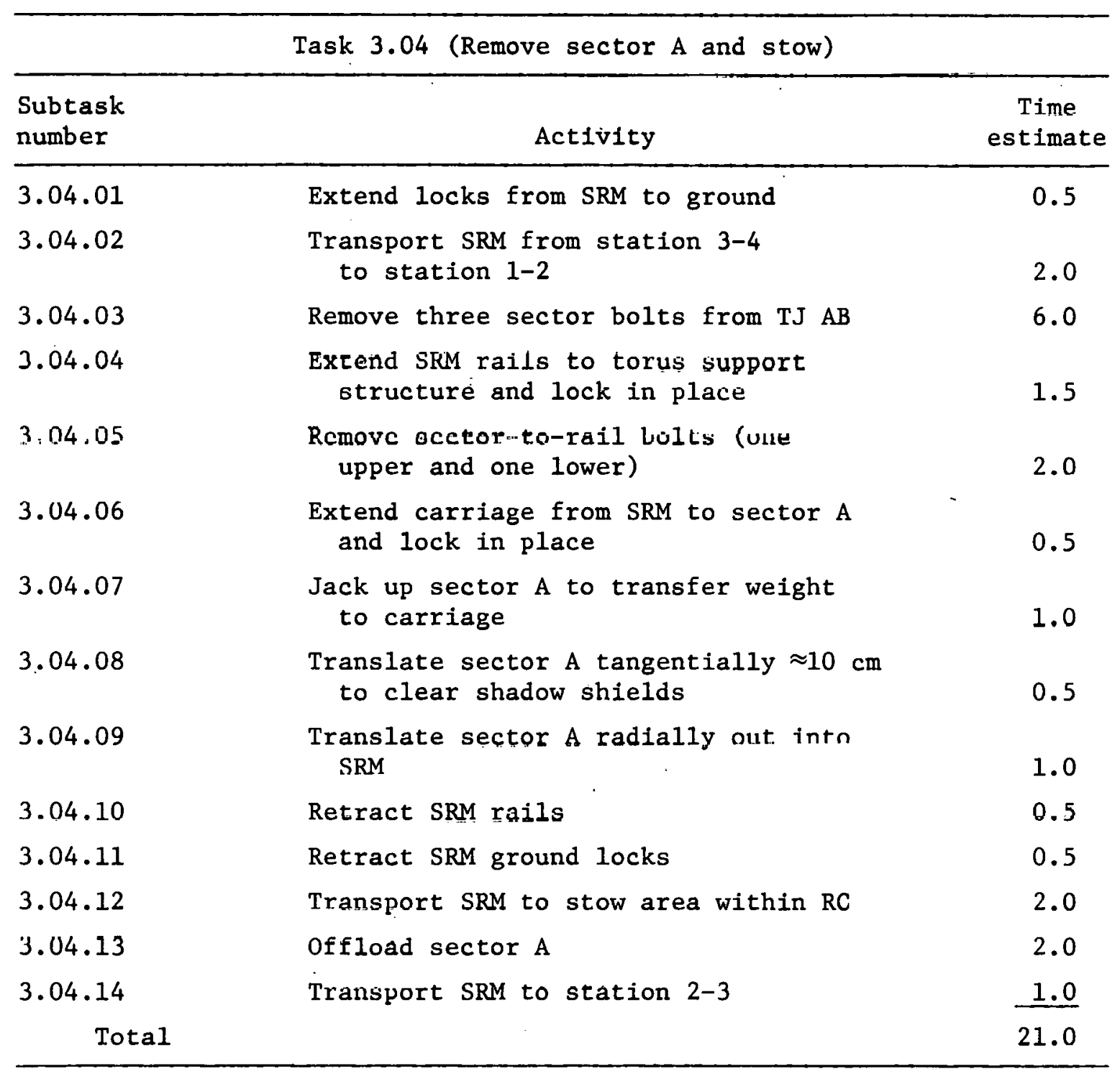


APPENDIX C

TNS (Bolted torus)

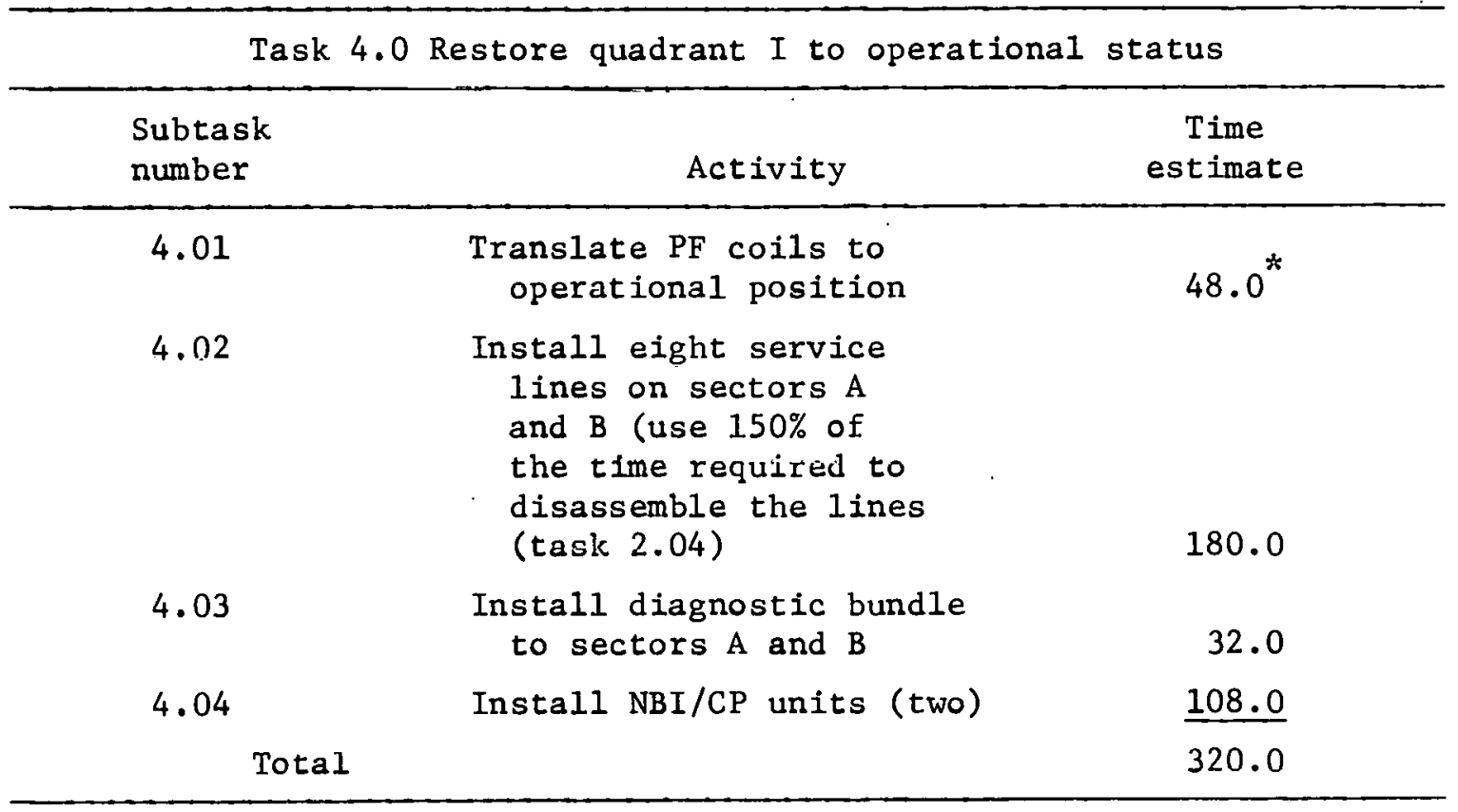

TNS (Bolted torus)

Task 5.0 Start up reactor

\begin{tabular}{|c|c|c|}
\hline $\begin{array}{l}\text { Subtask } \\
\text { number }\end{array}$ & Activity & $\begin{array}{l}\text { Time } \\
\text { estimate }\end{array}$ \\
\hline 5.01 & Close RC hatch and inflate seal & 1.0 \\
\hline 5.02 & Pump down RC & 6.0 \\
\hline 5.03 & Energize TF coils & $0.5^{*}$ \\
\hline 5.04 & $\begin{array}{l}\text { Fill coolant lines (shield and } \\
\text { first wall) of sectors } A \text { and } B\end{array}$ & $1.5^{*}$ \\
\hline 5.05 & Activate NBI & $6.0^{*}$ \\
\hline 5.06 & Activate torus VPS & $6.0^{*}$ \\
\hline 5.07 & $\begin{array}{l}\text { Operate divertor to remove } \\
\text { impurities }\end{array}$ & 24.0 \\
\hline \multicolumn{2}{|c|}{ Total } & 31.0 \\
\hline
\end{tabular}




\section{THIS PAGE \\ WAS INTENTIONALLY \\ LEFT BLANK}




\section{APPENDIX D}

\section{MAINTENANCE TASKS AND TIME ESTIMATES TO REPLACE ONE SECTOR OF A TNS DEVICE HAVING WELDED TORUS}

This section identifies the maintenance tasks required to replace one sector of a tokamak device which is similar to the TNS Reference Design as described in Sect. 4, with the exception that torus sectors are joined by welding rather than by mechanical means. The unit being replaced is sector $B$ of quadrant $I$. In order to remove sector $B$, sector A must first be removed and stowed. There are two NBI/CP units in quadrant $I$, and both must be removed to permit replacement of sector $B$.

All maintenance tasks are performed remotely and the estimated time for each task is given. The remote maintenance system (RMS) equipment used is as identified in Appendix $A$ and as follows.

- IVM (in-vessel manipulator) - a pair of dexterous arms that are used to disconnect and remove the first wall panels. It contains its own transport module and means for conveying itself from the transport module into the torus.

- MRU (module removal unit) - a special purpose conveyor unit that is inserted through an injector port and used to transport the first wall panels out of the torus and onto storage racks.

- CWM (cutter-welder module) - a device that is inserted into the torus and used to cut and reweld the torus joints. It contains its own transport module and means for conveying itself from the transport module into tho toruo.

A maintenance task that is conducted in parallel with other tasks is denoted (*), and the time required for its performance is not included in the total elapsed time. A maintenance task for which a detailed task breakdown is available is denoted $(t)$.

Abbreviations used are explained in Appendix A. 
APPENDIX D

TNS (Welded torus)

\begin{tabular}{|c|c|c|}
\hline & Replace sector B of quadrant I & \\
\hline Task & Activity & Time estimate \\
\hline 1.0 & Shut down & 1.5 \\
\hline 2.0 & Prepare quadrant I for sector replacement & 162.5 \\
\hline 3.0 & Exchange sector $B$ & 1764.0 \\
\hline 4.0 & Restore quadrant I to operational status & $312 . \overline{5}$ \\
\hline \multirow[t]{2}{*}{5.0} & Start up & 42.0 \\
\hline & & 2282.5 \\
\hline
\end{tabular}

TNS (Welded torus)

Task 1.0 Shut down

\begin{tabular}{|c|c|c|}
\hline $\begin{array}{l}\text { Subtaok } \\
\text { number }\end{array}$ & Activity & Time eslluale \\
\hline 1.01 & Discharge TF colls & $0.5^{*}$ \\
\hline 1.02 & $\begin{array}{l}\text { Drain conlant from sectors } A \text { and } B \\
\text { of quadrant } I\end{array}$ & $\underline{1.5}$ \\
\hline Total & & 1.5 \\
\hline
\end{tabular}


APPENDIX D

TNS (Welded torus)

Task 2.0. Prepare quadrant I for sector replacement

\begin{tabular}{|c|c|c|}
\hline $\begin{array}{l}\text { Subtask } \\
\text { number }\end{array}$ & Activity & $\begin{array}{c}\text { Time } \\
\text { estimate }\end{array}$ \\
\hline 2.01 & Open hatch & 0.5 \\
\hline 2.02 & $\begin{array}{l}\text { Prepare RC for maintenance operation; bring in } \\
\text { service lines; set up viewing system }\end{array}$ & 6.0 \\
\hline 2.03 & $\begin{array}{l}\text { Remove two NBI/CP units and stow. Note: duct } \\
\text { flanges have nonquick disconnect type }\end{array}$ & 56.0 \\
\hline 2.04 & $\begin{array}{l}\text { Remove two access plates on injector ports of } \\
\text { sectors C and D (total }=140 \text { bolts) }\end{array}$ & 24.0 \\
\hline 2.05 & $\begin{array}{l}\text { Disconnect coolant lines to sectors } A \text { and } B \text {. } \\
\text { Note: lines are mechanically clamped; } \\
\text { disconnect time }=50 \% \text { of time required } \\
\text { to remove welded lines per subtask } 2.04 \\
\text { of Appendix } C\end{array}$ & 60.0 \\
\hline 2.06 & Disconnect diagnostic bundle of sectors $A$ and $B$ & 16.0 \\
\hline 2.07 & Translate PF coils to stow position & $48.0^{*}$ \\
\hline 2.08 & $\begin{array}{l}\text { Install tiedown rods between torus and external } \\
\text { structure to preserve alignment during cut } \\
\text { and weld operation }\end{array}$ & $48.0^{*}$ \\
\hline Tot & & 162.5 \\
\hline
\end{tabular}


APPENDIX D

TNS (Welded torus)

Task 3.0 Exchange sector $B$

Subtask

number

Activity

Time estimate

\begin{tabular}{|c|c|c|}
\hline 3.01 & $\begin{array}{l}\text { Remove eight first wall panels from TJs } \\
\text { D(IV)A, } A B, B C \text {, and } D A(I I) \\
\text { (total }=32 \text { first wall panels) }\end{array}$ & $492.0^{+}$ \\
\hline 3.02 & $\begin{array}{l}\text { Cut torus joints (four places); } D(\text { IV)A, } \\
A B, B C \text {, and DA(II) }\end{array}$ & $106.0^{\dagger}$ \\
\hline 3.03 & Transport SRM from MC to RC (station 3-4) & $4.0^{*}$ \\
\hline 3.04 & Remove sector bolts at $\overline{\mathrm{T}} \mathrm{J} \overline{\mathrm{DA}}(\mathrm{II})$ & 6.0 \\
\hline 3.05 & Relocate SRM to station $2-3$ & 2.0 \\
\hline 3.06 & Remove sector bolts at $\mathrm{TJ} A B$ and $\mathrm{BC}$ & 12.0 \\
\hline 3.07 & Relocate SRM to station $1-2$ & 2.0 \\
\hline 3.08 & Remove sector bolts at TJ D(IV)A & 6.0 \\
\hline 3.09 & $\begin{array}{l}\text { Disconnect quadrant I lateral locks and } \\
\text { translate radially out to stop position }\end{array}$ & $12.0^{*}$ \\
\hline 3.10 & $\begin{array}{l}\text { Remove sector A, transport to MC, offload, } \\
\text { return SRM to RC station 2-3. Note: } \\
\text { this task is similar to subtask } 3.04 \text { of } \\
\text { Appendlx A }\end{array}$ & 22.0 \\
\hline 3.11 & Remove sector $B$, transport to $M C$, offload & 20.0 \\
\hline 3.12 & $\begin{array}{l}\text { Machine } T J A B \text { of sector } A \text {, weld spacer in } \\
\text { place to obtain } 22-1 / 2^{\circ} \text { between flanges; } \\
\text { this work is performed in } M C\end{array}$ & 24.0 \\
\hline 3.13 & $\begin{array}{l}\text { Machine ' } \mathrm{l} J \mathrm{BC} \text { of sector } C \text {; weld spacer in } \\
\text { place to obtain } 22-1 / 2^{\circ} \text { between flanges; } \\
\text { this work is performed in } \mathrm{RC}\end{array}$ & 48.0 \\
\hline 3.14 & Transport new sector $B$ to $R C$ and install & 22.0 \\
\hline 3.15 & Transport scceor $\Lambda$ to RC airl install. & 22.0 \\
\hline 3.16 & Install sector bolts at $\mathrm{TJ} A B$ and $B C$ & 12.0 \\
\hline 3.17 & $\begin{array}{l}\text { Translate quadrant I radially in and install } \\
\text { lateral locks }\end{array}$ & 12.0 \\
\hline 3.18 & Install sector bolts at TJ D(IV)A & 6.0 \\
\hline 3.19 & Relocate SRM to station $3-4$ & 2.0 \\
\hline 3.20 & Install sector bolts at $\mathrm{TJ}$ DA(II) & 12.0 \\
\hline
\end{tabular}


APPENDIX D

Task 3.0 (continued)

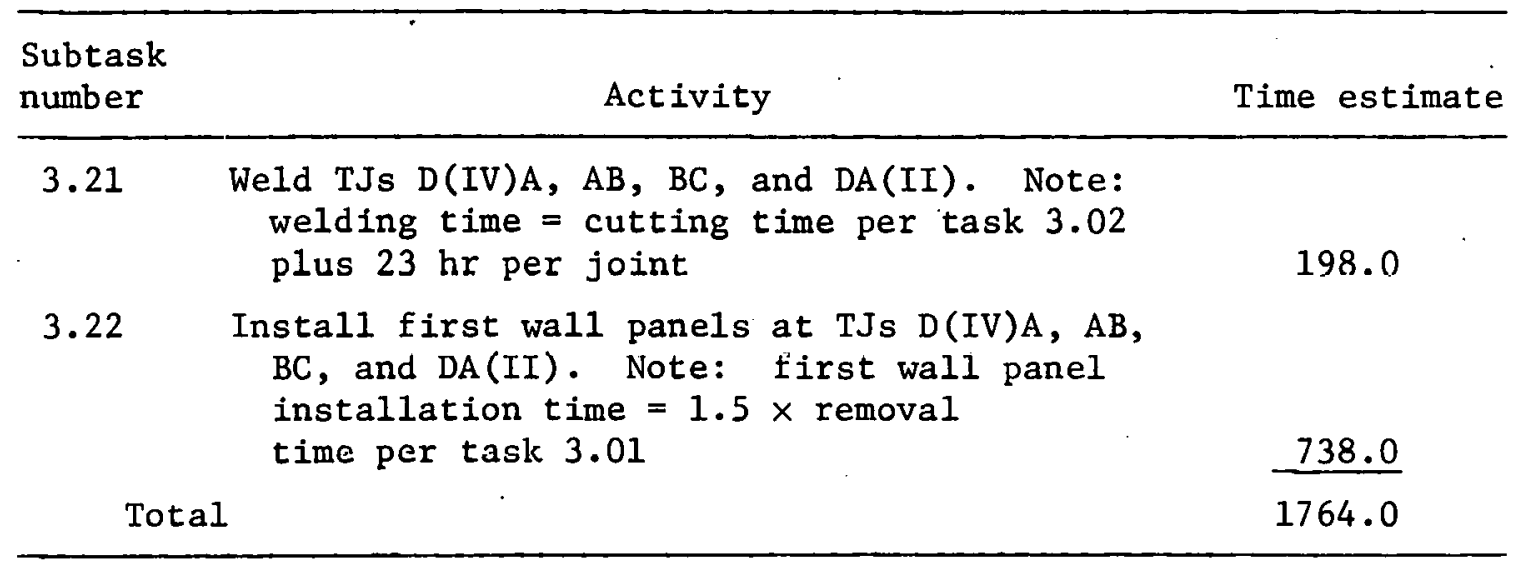


APPENDIX D

TNS (Welded torus)

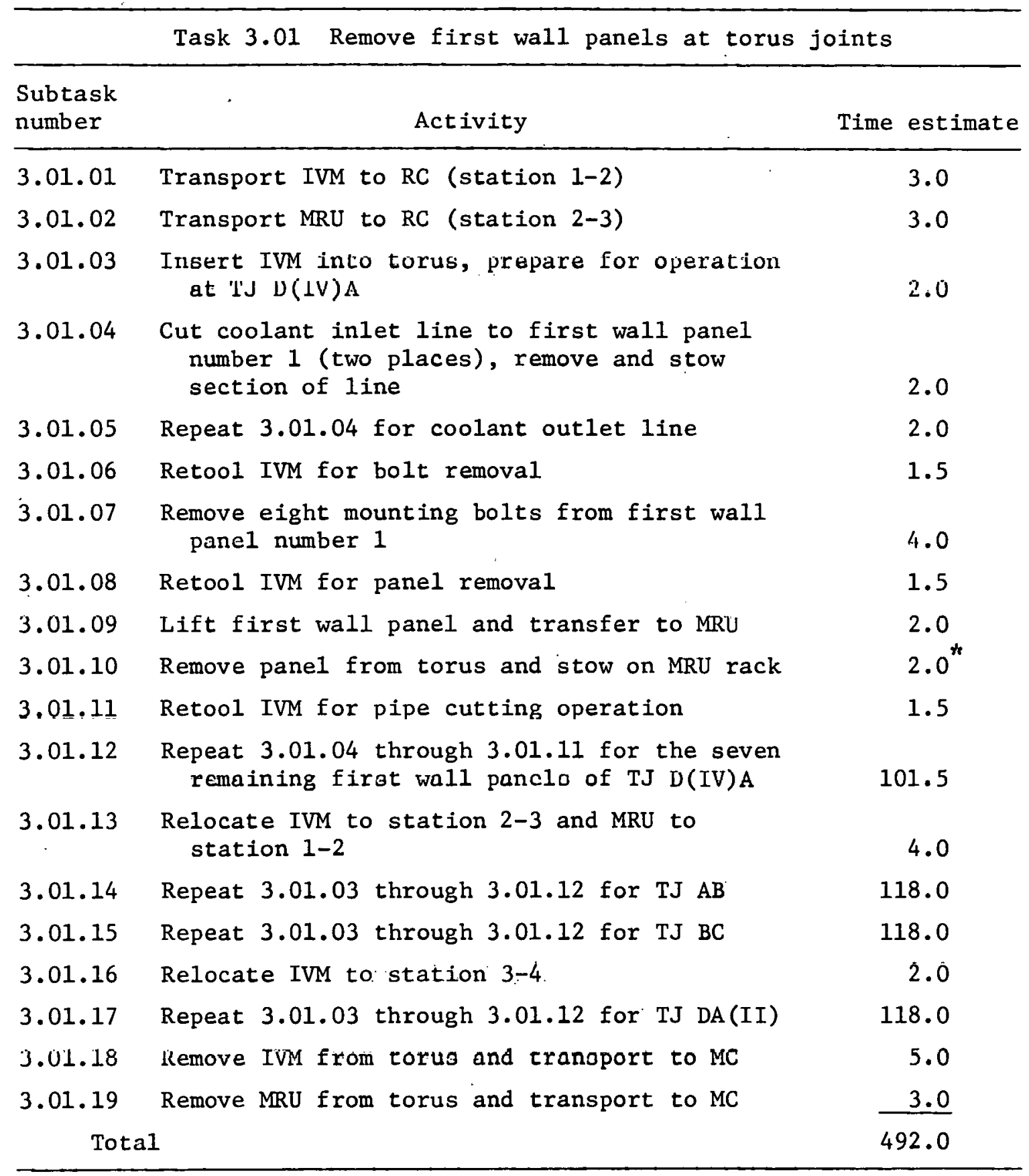




\section{APPENDIX D}

Task 3.02 Cut torus joint

\begin{tabular}{llr}
$\begin{array}{l}\text { Subtask } \\
\text { number }\end{array}$ & \multicolumn{1}{c}{ Activity } & $\begin{array}{r}\text { Time } \\
\text { estimate }\end{array}$ \\
\hline 3.02 .01 & Transport CWM to RC station 1-2 & 4.0 \\
3.02 .02 & $\begin{array}{l}\text { Insert CWM into torus and set up for cutting } \\
\text { operation on TJ D(IV)A }\end{array}$ & 4.0 \\
3.02 .03 & $\begin{array}{l}\text { Cut TJ D(IV)A. Note: cutting speed is 15 in./ } \\
\text { min; two cuts per TJ are required; a 4-hr }\end{array}$ & 18.0 \\
& tool change is required between cuts & 2.0 \\
3.02 .04 & Relocate CWM to TJ AB & 18.0 \\
3.02 .05 & Cut TJ AB & 4.0 \\
3.02 .06 & Retract CWM from torus & 2.0 \\
3.02 .07 & Transport CWM to station 2-3 & 22.0 \\
3.02 .08 & Repeat 3.02.02 and 3.02.03 for TJ BC & 4.0 \\
3.02 .09 & Retract CWM from torus & 2.0 \\
3.02 .10 & Transport CWM to station 3-4 & 22.0 \\
3.02 .11 & Repeat 3.02.02 and 3.02.03 for TJ D(IV)A & 4.0 \\
3.02 .12 & Retract CWM from torus & 4.0
\end{tabular}


APPENDIX D

Task 4.0 Restore quadrant I to operation status

\begin{tabular}{|c|c|c|}
\hline $\begin{array}{l}\text { Subtask } \\
\text { number }\end{array}$ & Activity & $\begin{array}{c}\text { Time } \\
\text { estimate }\end{array}$ \\
\hline 4.01 & Translate PF coils to operational position & $48.0^{*}$ \\
\hline 4.02 & $\begin{array}{l}\text { Install service lines on sectors } A \text { and } B \text {. Note: } \\
\text { use } 75 \% \text { of time required to install welded } \\
\text { service lines per subtesk } 4.02 \text { of Appendix } C\end{array}$ & 135.0 \\
\hline 4.03 & Install diagnostic bundles sectors $A$ and $B$ & $32.0^{*}$ \\
\hline 4.04 & $\begin{array}{l}\text { Install NBI/CP units. Note: use } 120 \% \text { of time } \\
\text { required to instal1 NBI/CP with quick dis- } \\
\text { connect per subtask } 4.04 \text { of Appendix } C\end{array}$ & 129.5 \\
\hline 4.05 & Remove torus tiedown rods & 48.0 \\
\hline \multicolumn{2}{|c|}{ Total } & 312.5 \\
\hline
\end{tabular}

Task. 5.0 Start up

\begin{tabular}{llr}
$\begin{array}{l}\text { Subtask } \\
\text { number }\end{array}$ & \multicolumn{1}{c}{ Activity } & $\begin{array}{c}\text { Time } \\
\text { estimate }\end{array}$ \\
\hline 5.01 & Close RC hatch & $0.5^{*}$ \\
5.02 & Fnergize TF coils & $0.5^{*}$ \\
5.03 & Fill first wall coolant lines on sectors A and B & $1.5^{*}$ \\
5.04 & Activate cryopump units & 6.0 \\
5.05 & Activate NBIs & $6.0^{*}$ \\
5.06 & Operate divertor to remove impurities & 36.0 \\
5.07 & Leak check TJs D(IV)A and DA(II) & $24.0^{*}$ \\
Total & & 42.0 \\
\hline
\end{tabular}




\section{APPENDIX E}

\section{CALCULATION OF SEAL CONDUCTANCE}

The conductance of the torus joint seal may be determined by the equation for molecular flow through a rectangular duct. 16

$$
F=9.7 \frac{a^{2} b^{2}}{(a+b) l}\left(\frac{T}{M}\right)^{1 / 2} \text { 1iters/sec, }
$$

where

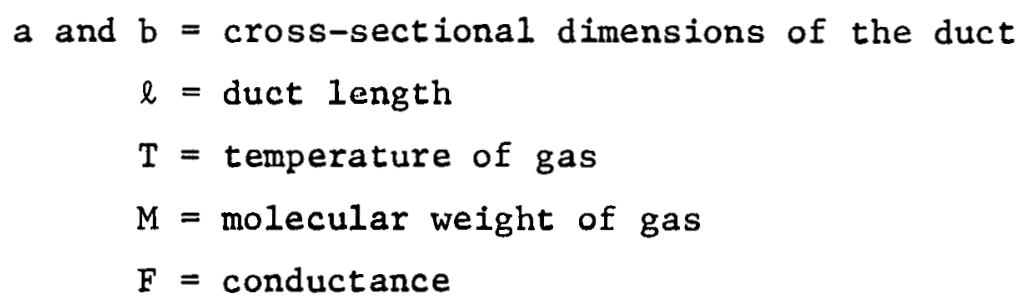

The seal is assumed to be off contact with the flange and the resultant gap has a height " $a$, " length " $b$, " and width " $l$." Note that " $l$ " is the dimension along the leakage path or the width of the seal. For our purposes, $b \gg \mathrm{a}$ and Eq. (E.1) may be simplified to:

$$
F=9.7 \frac{\mathrm{a}^{2} \mathrm{~b}}{\ell}\left(\frac{\mathrm{T}}{\mathrm{M}}\right)^{1 / 2}
$$

In Sect. 4.5, it was shown that seal conductance for tritium must be 96 liters/sec or less. Thus, if we assume gap height "a" of $1.0 \mathrm{~mm}$, we find the allowable gap length "b," using the following parameters:

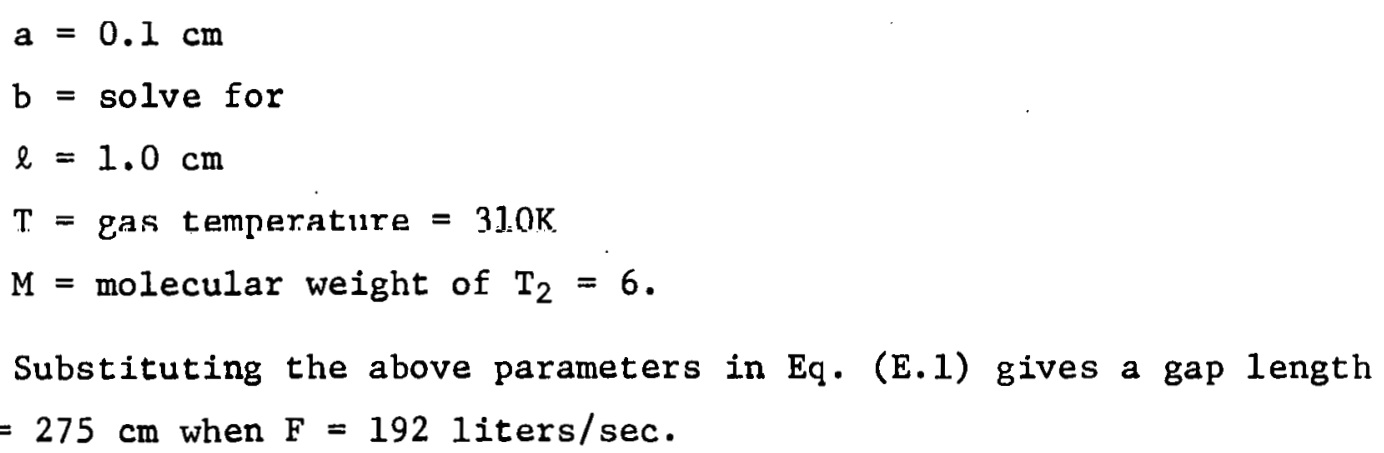


Since each torus joint has two seals in series, we assume that each seal has a conductance $F=19211$ ters/sec and the combined seal conductance is $F / 2=96$ iters $/ \mathrm{sec}$. 


\section{APPENDIX F \\ CALCULATION OF TORUS VACUUM PUMP SPEED REQUIRED \\ AT VARIOUS INLEAK RATES}

The torus vacuum pumps must remove postburn gasses within $25 \mathrm{sec}$ after each burn. The relationship of pumpdown time, pump speed, and inleakage is:

$t=f 2.2 \frac{V}{S} \log \left(\frac{P_{1}-\frac{Q}{S}}{P_{2}-\frac{Q}{S}}\right)$.

Parameters are:

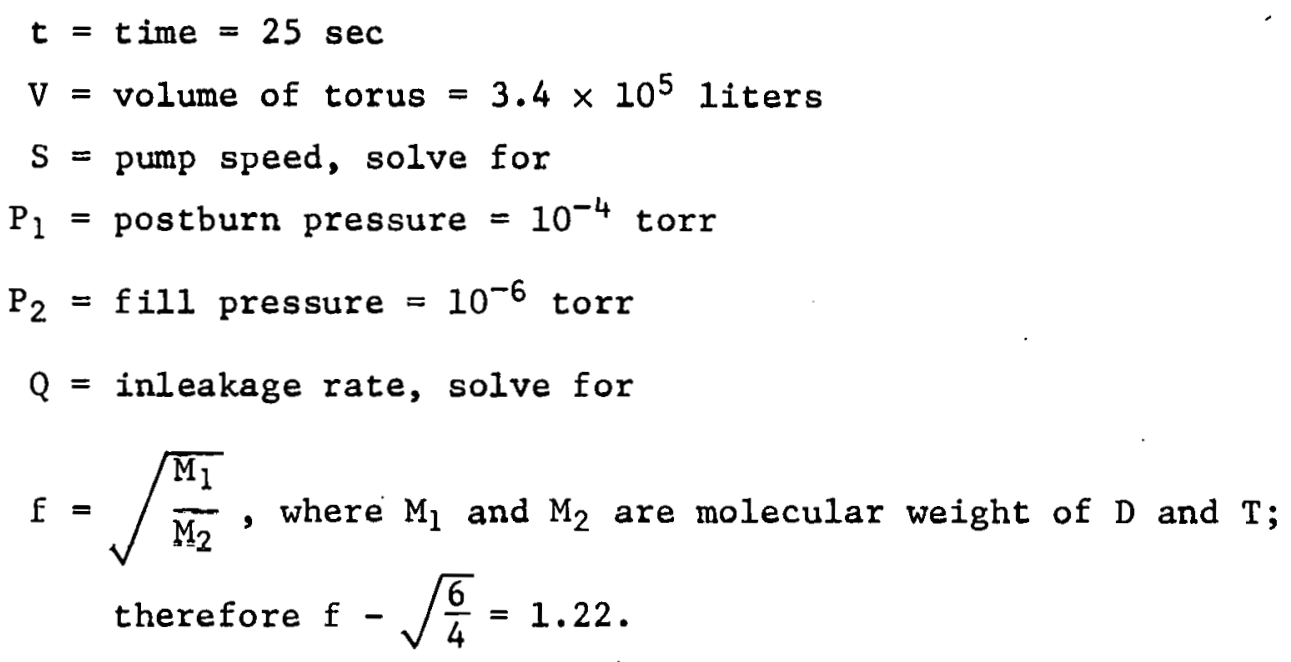

Equation F.1 may be transposed as follows:

$Q=S \frac{\left(P_{2} 10 \frac{S t}{f 2.2 V}-P_{1}\right)}{\left(10 \frac{S t}{f 2.2 V}-1\right)}$

Equation F.2 was solved for values of $S=7.3 \times 10^{4}$ through $S=12 \times 10^{4}$ liters/sec, and the results are shown graphically in Fig. 6.3. The maximum rate of torus inleakage occurs when the cell pressure is $10^{-4}$ turr, the in-cell gasses are primarily hydrogenic types having a molecular weight of two, and the seal gap is $1 \mathrm{~mm} \times 275 \mathrm{~cm}$, as 
determined in Sect. 4. The hydrogen conductance of the seal is 163 liters/ $\mathrm{sec}$, as determined by Eq. E.2. Under these conditions, torus inleakage is $10^{-4}$ torr $\times 16311$ ters/sec or 0.0163 torr 1 iters $/ \mathrm{sec}$. 


\section{REFERENCES}

1. W. M. Stacey, Jr. et al., Tokcomak Experimental Power Reactor Conceptual Design, Argonne National Laboratory Report ANL/CTR-76-3 (1976).

2. C. C. Baker et al., Experimental Power Reactor Conceptual Design Study - Final Report for the Period July 1, 1974 through June 30, 1976, General Atomic Company Report GA-A14000 (1976).

3. J. T. D. Mitche11 and A. A. Hollis, "A Tokamak Reactor with Servicing Capability,"Pruc. 9th SOFT Conf., Garmisch-Partenkirchem, p. 429 (1976).

4. Richard W. Werner, ORNL Fusion Power Demonstration Study: Arguments for a Vacuzon Building in which to Enclose a Fusion Reactor, Oak Ridge National Laboratory Report ORNL/TM-5664 (December 1976).

5. Space Power Facility Description and Capabilities, internal document, NASA Lewis Research Center, Plum Brook, Ohio, Sandusky, Ohio (June 1974).

6. D. J. Santeler et a1., Vacurm Technology and Space Simulation, NASA Report SP-105 (1966).

7. Space Shuttle Remote Manipulator System: Design Definition Report, R776, SPAR, Toronto, Canada.

8. Manual Remote Work Station Development Article - Final Report, Gromman Aerospacie Cuiporation, MASA Report MR-RP 008 (1979).

9. D. Steiner et al., Oak Ridge TNS Program: Sumary of FY 1978 Activities, Oak Ridge National Laboratory Report ORNL/TM-6720 (July 1979).

10. R. Delvecchio (Gruman Aeroepace Corporation, Life Sciences Dept.), private communication.

11. Electrical Engineers' Handbook, 10th edition, McGraw-Hi11, New York.

12. T. G. Brown, G. W. Weisman, and Y-K. M. Peng, Oak Ridge TNS Progrom: Evaluation of the Poloidal Field. System. (to be published).

13. L. Reid et al., Oak Ridge TNS Program: S'ystem Deuciniption Manual, Oak Ridge National Laboratory Report ORNL/TM-6721 (May 1979).

14. W. Wells, Oak Ridge TNS Progrom: Evaluation of the Bundle Divertor, Oak Ridge National Laboratory Report ORNL/TM-6727 (September 1979). 
15. T. J. Huxford et a1., Tokamak Blanket Design Study: FY 1978 Sromaxy Report, Oak R1dge National Laboratory Report ORNL/IM-6847 (June 1979).

16. Saul Dushman and J. M. Lafferty, Seientific Foundations of Vacurm Technique, 2nd ed., Wiley, New York. 
ORNL/TM-6725

Dist. Category UC-20 d

\section{INTERNAL DISTRIBUTION}

1. W. R. Becraft

2. L. A. Berry

3. P. N. Haubenreich

4. W. A. Houlberg

5. T. J. Huxford

6. M. S. Lubel1

7. 0. B. Morgan

8. H. Postma

9. R. L. Reid

10. J. A. Rome

11. M. W. Rosenthal

12. J. L. Scott

13. T. E. Shannon
14. J. Sheffield

15. D. Steiner

16. N. A. Uckan

17. J. S. Watson

18. F. W. Wiffen

19-20. Central Research Library

21-22. Fusion Energy Division Library

23. Fusion Energy Division Communications Center

24-25. Laboratory Records Department

26. Laboratory Records, ORNL-RC

27. ORNL Patent Office

28. Document Reference Section

\section{EXTERNAL DISTRIBUTION}

29. D. J. Anthony, General Electric Co., Bldg. 23, Rm. 290, 1 River Rd., Schenectady, NY 12345

30. J. E. Baublitz, Office of Fusion Energy, Department of Energy, Washington, DC 20545

31. D. S. Beard, Office of Fusion Energy, Department of Energy, Washington, DC 20545

32. S. I. Bogart, Science Applications, Inc., 8400 Westpark Drive, McLean, VA 22102

33. R. Botwin, Grumman Aerospace Corp., Bethpage, NY 11714

34. J. D. Callen, Nuclear Engineering Department, Iniversity of Wisconsin, Engineering Research Building, 1500 Johnson Drive, Madison, WI 53706

35. J. F. Clarke, Office of Fusion Energy, Department of Energy, Washingtón, DC 20545

36. F. E. Coffman, Office of Fusion Energy, Department of Energy, Washington, DC 20545

37. D. Cohn, Massachusetts Institute of Technology, Cambridge, MA 02139

38. Library, Culham Laboratory, Abingdon, Oxon, OX14 3DB, United Kingdom

39. S. O. Dean, Director, Fusion Energy Development, Science Applications, Inc., 2 Professional Drive, Suite 249, Gaithersburg, MD. 20760

40. H. W. Deckman, Advanced Energy Systems Laboratory, Government Research Laboratories, Exxon Research and Engineering Co., P.0. Box 8, Linden, NJ 07306

41. C. A. Flanagan, Westinghouse Electric Corp., Fusion Power Systems, P.o. Box 10864, Pittsburgh, PA 15236

42. H. K. Forsen, Exxon Nuclear Co., Inc., 777 106th Ave., Bellevue, WA 98009 
43. H. P. Furth, Princeton Plasma Physics Laboratory, Princeton University, P.0. Box 451, Princeton, NJ 08540

44. R. W. Gould, Mail Stop 116-81, California Institute of 'Technology, Pasadena, CA 91125

45. R. Hancox, Culham Laboratory, Abingdon, Oxon, Ox14 3DB, United Kingdom

46. C. R. Head, Office of Fusion Energy, Department of Energy, Washington, DC 20545

47. R. L. Hirsch, Exxon Research and Engineering Co., P.0. Box 101, Florham Park, NJ 07932

48. M. A. Hoffman, Lawrence Livermore Laboratory, P.0. Box 808, Livermore, CA 94550

49. Anthony Hsu, Office of Fusion Energy, Department of Energy, Washington, DC 20545

50. D. L. Jassby, Princeton Plasma Physics Laboratory, Princeton University, F.0. Dox 451, PL Lncelun, NJ 08540

51. V. A. Maroni, Argonne National Laboratory, 9700 South Cass Ave., Argonnc, IL 60439

52. D. M. Meade, Princeton Plasma Physics Laboratory, Princeton University, P.0. Box 451, Princeton, NJ 08540

53. P.B. Mohr, Lawrence Livermore Laboratory, P.0. Box 808, Livermore, CA 94550

54. M. R. Murphy, Office of Fusion Energy, Department of Energy, Washington, DC 20545

55. J. M. Rawls, General Atomic Co., P.0. Box 81608, San Diego, CA 92138

56. P. Reardon, Princeton Plasma Physics Laboratory, Princeton University, P.0. Box 451, Princet.on, N.T n8540

57. T. Reuther, Office of Fusion Energy, Department of Energy, Washington, DC 20545

58. M. Roberts, Office of Fusion Energy, Department of Energy, Washington, DC 20545

59. P. H. Geger, Jr., Genéral Aturnlc Co., P.0. Box 81608, Sar Diego, CA 92138

60. G. Schilling, Princeton Plasma Physics Laboratory, Princeton University, P.0. Box 451, Princeton, N.J 08540

61. W. M. Stacey, Jr., School of Nuclear Engineering, Georgia Insc1cure of Technology, At lanta, GA 30332

62. F. Thomas, Grumman Aerospace Corp., Bethpage, NY 1.1 .714

63. T. C. Varljen, Westinghouse Electric Corp., Fusion Power Systems, P.0. Box 10864, Pittsburgh, PA 15236

64. S. S. Waddle, Department of Energy, Oak Ridge Operations, P.0. Box E, Oak Ridge, 'I'N j/Uju

65-75. J. S. Walker, University of Illinols, Urbana, IL 61801

76. J. Willis, Office of Fusion Energy, Department of Energy, Washington, DC 20545

77. W. Wilkes, Mound Laboratories, Miamisburg, OH 45432

78. k. Liurys, Office of Fusion Energy, Department of Energy, Washington, DC 20545

79. K. Zwilsky, Office of Fusion Energy, Department of Energy, Washington, DC 20545 
80. Office of Assistant Manager, Energy Research and Development, Department of Energy, Oak Ridge Operations, P.O. Box E, Oak Ridge, TN 37830

81-217. Given distribution as shown in TID-4500, Magnetic Fusion Energy

$8($ (Distribution Category UC-20 d, Fusion Systems) 